\title{
The Growth Factors Involved in Microalgae Cultivation for Biofuel Production: A Review
}

\author{
Kamrul Hasan Chowdury, Nurun Nahar, Ujjwal Kumar Deb* \\ Department of Mathematics, Chittagong University of Engineering \& Technology, Chittagong, Bangladesh \\ Email: mkchowdury@cuet.ac.bd, nahar@cuet.ac.bd, *ukdebmath@cuet.ac.bd
}

How to cite this paper: Chowdury, K.H., Nahar, N. and Deb, U.K. (2020) The Growth Factors Involved in Microalgae Cultivation for Biofuel Production: A Review. Computational Water, Energy, and Environmental Engineering, 9, 185-215. https://doi.org/10.4236/cweee.2020.94012

Received: August 30, 2020

Accepted: October 27, 2020

Published: October 30, 2020

Copyright ( 2020 by author(s) and Scientific Research Publishing Inc. This work is licensed under the Creative Commons Attribution International License (CC BY 4.0).

http://creativecommons.org/licenses/by/4.0/

\begin{abstract}
The growing demand for energy and the negative environmental impacts of fossil fuel use are triggering global searches for a renewable and eco-friendly alternative biofuel. Microalgae are considered as one of the most promising feedstocks for biofuel production, due to many advantages including cultivation in non-arable land and being able to grow in wastewater or seawater. That is why; microalgae-based biofuels are regarded as one of the best candidates to replace fossil fuels. There are two main types of microalgae cultivation systems: Open Raceway Ponds and Closed Photobioreactos (PBRs). Due to some limitations in Open Raceways, PBRs have become the most favorable choice for biofuel producers, even though it is costly. To make the process viable, the growth of microalgae for biofuel production should be cost-effective. One way to achieve this goal is to optimize the environmental factors that influence their growth during the cultivation stage to increase the accumulation of bio-compounds of fuel. Algal growth relies mostly on nutrients, $\mathrm{CO}_{2}$ concentration, $\mathrm{pH}$ and salinity, light intensity and quality, temperature and finally mixing, which directly affects all other factors. Thus, before designing PBR, a thorough study on these growth parameters is needed. In the present study, we reviewed and evaluated these growth influencing factors in an extensive way to optimize biofuel production.
\end{abstract}

\section{Keywords}

Microalgae, Biofuel, Photobioreactor, Cultivation, Growth Factors

\section{Introduction}

The energy crisis is increasing day-by-day due to the heavy industrial development and exponential growth of population. Fossil fuel sources like diesel, petrol, coal natural gas are depleting due to their extensive usage in motor vehicles 
and industries. Furthermore, release of huge amount of toxic and harmful gases into the atmosphere pollutes the environment severely because of the continuous use of fossil fuels in different sectors. Level of greenhouse gas (GHG) is also increasing in an arming rate, releasing $\mathrm{CO}_{2}$ into the atmosphere and rising temperature which leads to the global warming. Among other gases, $\mathrm{CO}_{2}$ is considered the major pollutant which damages environment the most. Although the pollutant gases are present in the atmosphere at an endurable rate, due to the emissions from the vehicles and industries, their concentration has increased over the past few decades. Imposing all these negative impacts on the environment, a major climatic change has been observed over the entire globe. At this junction, replacement of fossil fuels with other eco-friendly alternative sources is the best solution to avoid upcoming catastrophe. Microalgae based biofuel could be a very promising alternative in this aspect.

In 1942, Harder and von Witsch [1] first recommended that microalgae could be viable sources of lipids which can be used as food or to produce biofuels. Since then, enormous efforts have been given in research involving microalgae and their bioproducts. Microalgae are considered as one of the most promising sources for bioenergy production now-a-days [2] [3] [4].

The biofuels produced from microalgae have several advantages compared with that from conventional oil seeds. These include the ability to use non-arable land for microalgal cultivation, the higher productivities and possibility to use wastewater and gas flue as source of carbon and nutrients to promote the growth of microalgae [5] [6]. Though microalgae can produce different types of biofuels, such as biodiesel, bioethanol, biohydrogen, syngas, biobutanol, and bioelectricity [7] [8], yet the majority of economic analyses conclude that microalgae biofuels cannot compete with conventional fuels because of its high price [9] [10].

To minimize the production cost, industrialization of microalgae products needs large-scale culture systems. Two major types of microalgae cultivation systems are 1) Open Raceway Ponds (Figure 1) and 2) Closed Photobioreactos (PBRs) (Figure 2). Though open systems are much cheaper and easier to manage than closed systems, they have many operational problems as well, such as

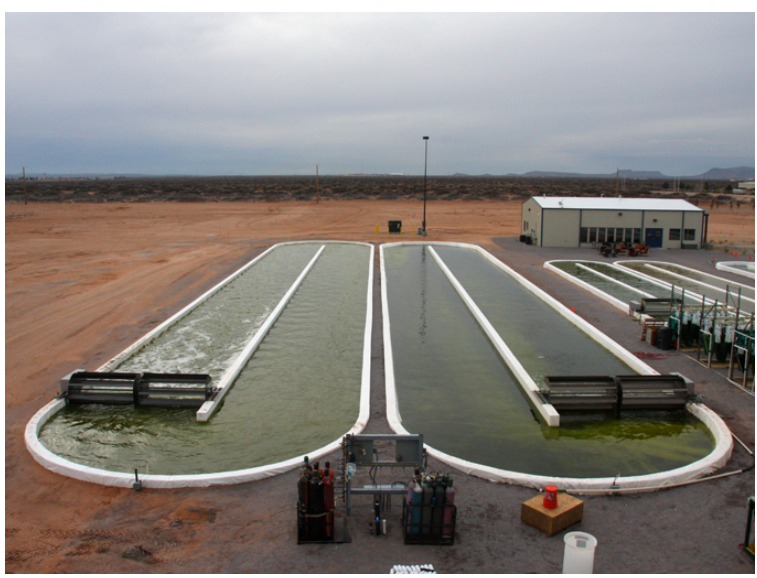

Figure 1. Open raceway ponds. 


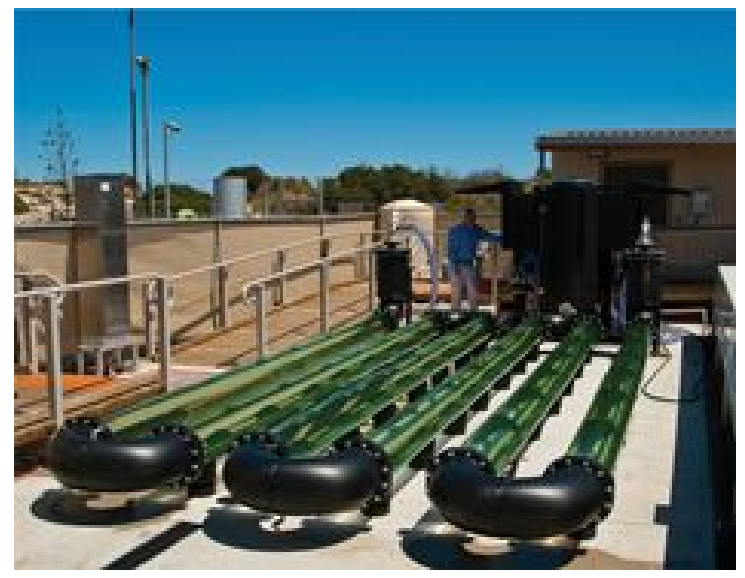

Figure 2. Closed Photobioreactors (PBRs).

evaporation, contamination, susceptibility to weather conditions and huge amount of land requirements [11]. On the contrary, these limitations can be overcome by closed systems with high capital costs. In order to reduce these limitations, researchers have been invested a large amount of money in the development of new PBR designs due to the high operational control and the high productivity provided by the PBRs and thus make microalgae-based processes viable [7] [12] [13].

Microalgal growth is influenced by a variety of culture parameters, such as light intensity, $\mathrm{pH}$, salinity, nutrients availability, temperature, $\mathrm{CO}_{2}$ and dissolved oxygen concentration. Therefore, these culture parameters should be optimized to improve biomass productivity. To design a PBR for optimizing the production of microalgae, a thorough study on growth parameters is important. In the present study, we reviewed and evaluated these parameters for optimizing PBR performance. Since the design of PBR is also responsible for the microalgal growth, a short description of PBR is given at the beginning of the study.

\section{Photobioreactor (PBR)}

PBRs are artificial cultivation system which favors the growth of selected strain under optimal conditions such as configuration, light, temperature, $\mathrm{pH}$, nutrient, mixing, etc. For commercial microalgal biomass production, closed PBRs, especially tubular PBRs have been used successfully in recent years. Due to good control of culture conditions and high solar radiation availability and thus high biomass productivity, unlike open raceways, tubular PBRs have become a potential system for biofuel production and compounds of high commercial value [14] [15].

A tubular PBR mainly consists of an array of straight transparent tubes, having a diameter of $0.1 \mathrm{~m}$ or less and are usually made of plastic or glass [16]. In order to maximize the sunlight capture, these transparent tubes can be arranged in different patterns (e.g., straight, bent, or spiral) and orientations (e.g., horizontal, inclined, vertical, or helical) and thus having different names, such as tubular, helical, horizontal PBR, etc. [17]. However, to scale-up the production, 
the tubes are usually arrayed in a horizontal fence-like, which in one hand improves the land utilization, and on the other hand has a better angle for incident light [18].

Since the transparency of the materials and the surface/volume ratio are responsible for the light capture, Glass, plexiglass, polyvinyl chloride (PVC), acrylic-PVC, and polyethylene are the most common materials that are used for PBR construction. All these materials have appropriate transparency for the microalgae cultivations. However, since they all have their merits and demerits, so before using a type, it must need to be evaluated according to the type of process and desired product. Though glass is strong and transparent and very good material for the construction of laboratory-scale PBRs, yet it requires many connection parts for the construction of large-scale PBRs, which could be costly. For this reason, the plastic type, mainly of polyethylene is most suitable for large-scale tubular PBR [19].

PBR can be illuminated by either artificial or natural light. Though the artificial illumination is technically possible, it is expensive compared with outdoor cultivations, which is just viable for commercial production of high added value products [20].

\section{Major Factors Affecting the PBR Performance}

The salient components for algal growth are a growth medium with a source of light energy for photosynthesis, proper nutrients and $\mathrm{CO}_{2}$ or air flow. Algal growth is also affected by several environmental parameters such as temperature, $\mathrm{pH}$, salinity, oxygen concentration and processing parameters such as mixing and light intensity. As the culture condition varies from species to species, all of these growth factors must be specified for successful microalgae cultivation for a specific purpose [21].

\subsection{Light Intensity and Quality}

Availability of the light is the most important factor in the growth and productivity of photosynthetic microorganisms. As light is the main energy input for photosynthetic microorganisms, it must be maximized for better output. However, excess of light particularly coupled with sub-optimal temperature or high oxygen level can damage the photosynthetic apparatus [22]. Therefore, by adequate design of its geometry and orientation, light supply to the cultivation system must be optimized [23] [24]. The amount of light received by the cultured cells is directly related to the carbon influencing the growth rate of the cultures [25]. The growth of microalgae is determined by the photosynthesis rate, which is a direct function of the irradiance to which the cells are exposed inside the culture. Figure 3 shows the variation of photosynthetic rate with the luminous intensity. As light intensity increases, photosynthesis in microalgae also increases until it reaches a maximum rate at the saturation point (Figure 4) [26] [27] [28]. Above the saturation point, the excess light leads to a phenome 


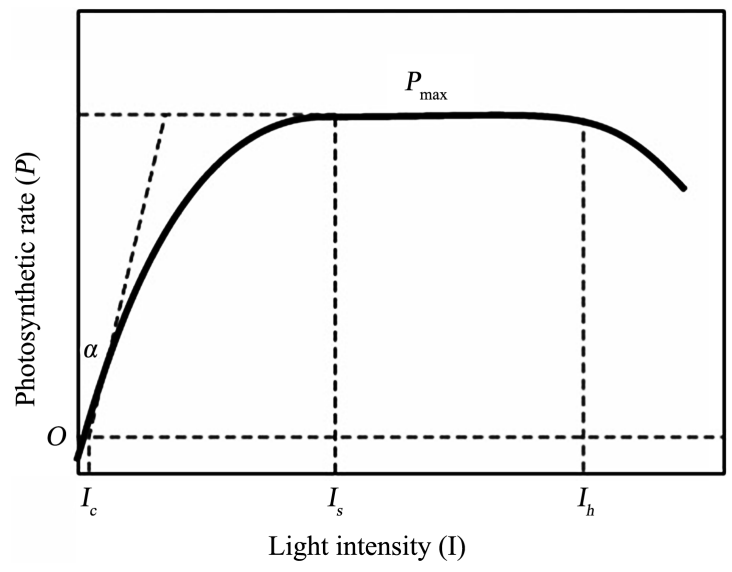

Figure 3. Variation of the photosynthetic rate with the light intensity.

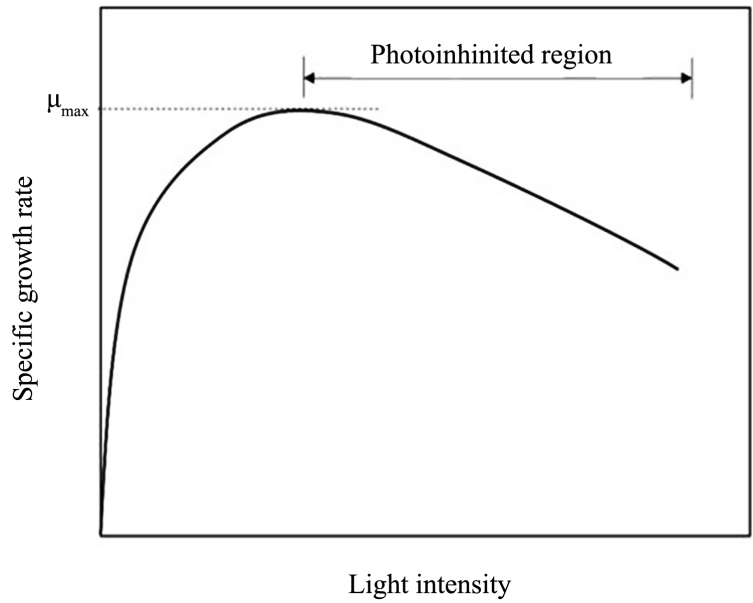

Figure 4. Effect of the light intensity on the specific growth rate of microalgae.

non called photoinhibition. The culture is then said to be photoinhibited. This irradiance is called the inhibition irradiance. For most microalgae, photosynthesis is saturated at 100 to $500 \mu \mathrm{E} \cdot \mathrm{m}^{-2} \cdot \mathrm{s}^{-1}$, although the maximal productivity is obtained at the Average Irradiance (AI) values close to constant irradiance in the range of $50-100 \mu \mathrm{E} \cdot \mathrm{m}^{-2} \cdot \mathrm{s}^{-1}$ [29] [30]. The photoinhibition appears at the irradiances level over $1000 \mu \mathrm{E} \cdot \mathrm{m}^{-2} \cdot \mathrm{s}^{-1}$ in most strains, although some sensitive strains are photoinhibited at lower irradiances down to $300 \mu \mathrm{E} \cdot \mathrm{m}^{-2} \cdot \mathrm{s}^{-1}$ [31].

The irradiance is defined as the amount of radiation reaching a point from all directions in space, at every wavelength. However, only Photosynthetically Active Radiation (PAR), range from 400 to $700 \mathrm{~nm}$, is used by microalgae to perform photosynthesis, whatever the light source is (sun, lamps, LEDs) [32]. Due to mutual shading the irradiance inside microalgae cultures is not homogeneous but a function of light intensity, culture depth, and biomass concentration. Thus cells in the outer part of the culture can be exposed to high irradiances, whereas in the inner part of the culture, cells can be in complete dark. The concept of AI was proposed to solve this problem [33] [34]. According to this concept, the AI at which the cells are exposed to inside a culture is calculated as the volumetric 
integral of the corresponding local irradiance in all the points inside the culture. This local irradiance can be calculated by applying Lambert's law for the radiation arriving to the reactor surface. The value of AI is really important because this concept allows normalizing the light conditions in whatever microalgae culture system, allowing calculating an intensive variable representing the "concentration of light" inside the culture. Thus the AI can be used to analyze or model the growth of whatever microalgae as usually performed with bacteria or other heterotrophic microorganisms when considering substrate concentration. In microalgae cultures the growth-irradiance response curves have a hyperbolic shape (Figure 5) [35] [36]. In this curve the saturation irradiance $\left(I_{s}\right)$ is the irradiance above which the growth is saturated, whereas constant irradiance $\left(I_{k}\right)$ is the irradiance at which the growth is equal to half of the maximal specific growth rate. Therefore, the influence of light on the growth of any particular strain must be studied in each particular location as it varies from place to place. Gonçalves et al. [37] evaluated the effect of light on the growth of microalgae ( $C$. vulgaris, P. subcapitata, Microcystis aeruginosa and Synechocystis salina) and nutrients uptake. In the case of $C$. vulgaris, these authors found that the optimum daily irradiance was $208 \mu \mathrm{E} \cdot \mathrm{m}^{-2} \cdot \mathrm{s}^{-1}$.

It has been reported that the optimal condition for the growth of microalgae will depend not only on the light intensity but also on the wavelength and the photoperiod to which the cells are exposed [38]. As microalgae need light for their metabolic activity, its growth is strongly influenced by this culture parameter, both in terms of quality (wavelength, the light source used, among others) and quantity (light intensity and light period). The light source can be either artificial or natural (solar). Though the latter being the most economically viable due to its availability, in high value-added cultures, artificial light can also be employed because it allows the precise control of photosynthesis and photope$\operatorname{riod}[39]$.

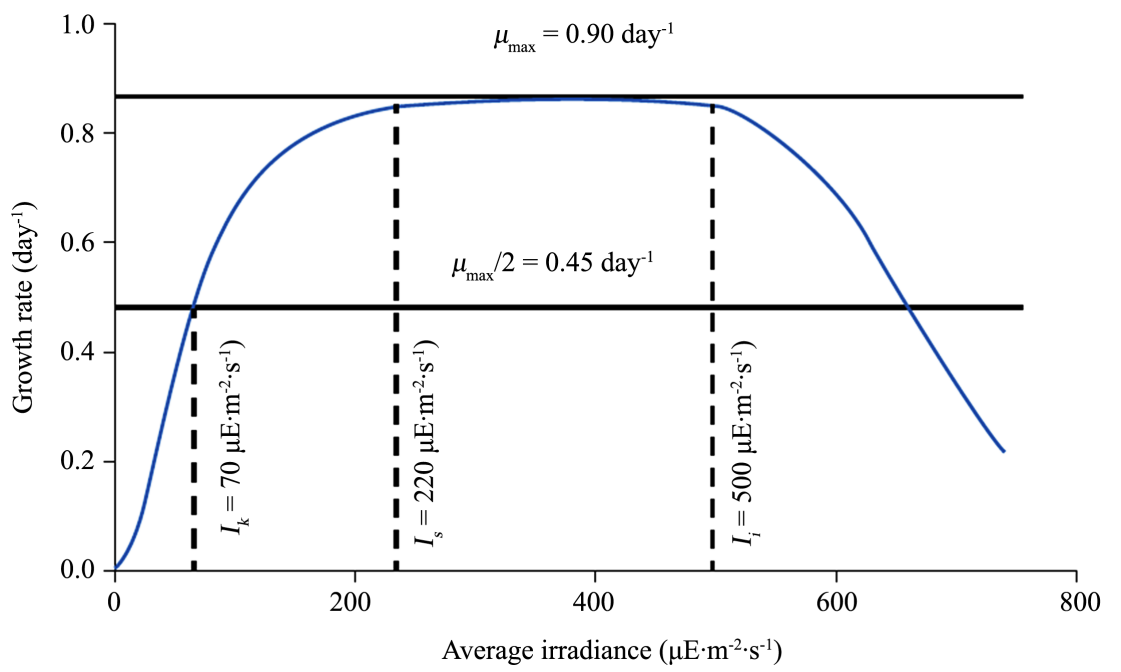

Figure 5. Growth-irradiance response curve of Scenedesmus almeriensis indicating the value of characteristics variables for this strain. 
Different artificial light sources can be used for microalgal cultivation, such as Light-Emitting Diodes (LEDs), halogen lamps, fluorescent lamps and incandescent bulbs. These light sources vary from each other in energy consumption, spectrum, wavelength distribution and cost. Considering all these characteristics, fluorescent lamps and LEDs are the most commonly used light sources for microalgal production. Comparing with the fluorescent lamps, the use of LEDs has better control of light and the use of different wavelengths, which can be favorable for biomass production [40]. The depth that the light can reach in the culture is independent of the light intensity. Thus, for complementing the natural light, or even for cultures under the artificial light, it is recommended to place LEDs inside the medium to improve the delivery and distribution of photons [41].

Due to the stirring system in microalgae culture tanks, there are the light/dark (L/D) cycles found in the medium. These cycles are responsible for the increase in the photosynthetic conversion and biomass productivity in microalgae, reported by Takache et al. [42]. The same authors reported that the efficiency of photosynthesis in Chlamydomonas reinhardtii was enhanced when L/D cycles of less than $20 \mathrm{~s}$ were applied, with an increase in the growth rate of up to $40 \%$, depending on the conditions of the L/D cycle.

The variation of light wavelength has significant impact in the microalgal growth. The red light can promote higher growth rates with smaller cells and low nutrient uptake. On the other hand, the blue light affects gene expression and some metabolic pathways of microalgae, triggering a high nutrient uptake, but inducing lower growth rates with the larger cells. Due to the lack of phycobilins, green microalgae cannot use yellow and green light effectively [43]. Satthong et al. [44] studied the light effect on the growth of $C$. vulgaris TISTR8580. Their obtained results are shown in Figure 6. It illustrates the number of $C$. vulgaris cells at different times and conditions. They have carefully studied the growth of $C$. vulgaris from algae cells cultured under the different light sources, including the white LED light, the red LED light, and the fluorescence light. From the experiments, it was observed that the microalgae are in a state of lag phase during day 0 and day 1 . In this period, the algae population remains constant as they are adapting to the new environment. However, the cell density increases dramatically during day 2 to day 3 , as compared to day 1 . This reflects the typical nature of the exponential growth phase, namely the fast-growing phase. After day 4 to the last day of the experiment, the algae are in a stationary state phase in which the algae population is consistently at maximum. They experimentally found that the white LED light source gives the highest population density on day 14 at $66.63 \times 10^{6} \mathrm{cell} / \mathrm{ml}$. Algae under a fluorescent light source with the white light had the highest density on day 14 at $79.33 \times 10^{6} \mathrm{cell} / \mathrm{ml}$. The algae under the red LED light source give the highest density on day 3 at $76.83 \times$ $10^{6} \mathrm{cell} / \mathrm{ml}$. Although the cell density of the algae under the red LED light is more than that under white LED light, during the stationary state phase on day 3 , the cell density under red LED light is decreased more than that in the case of the white LED light on day 4. 


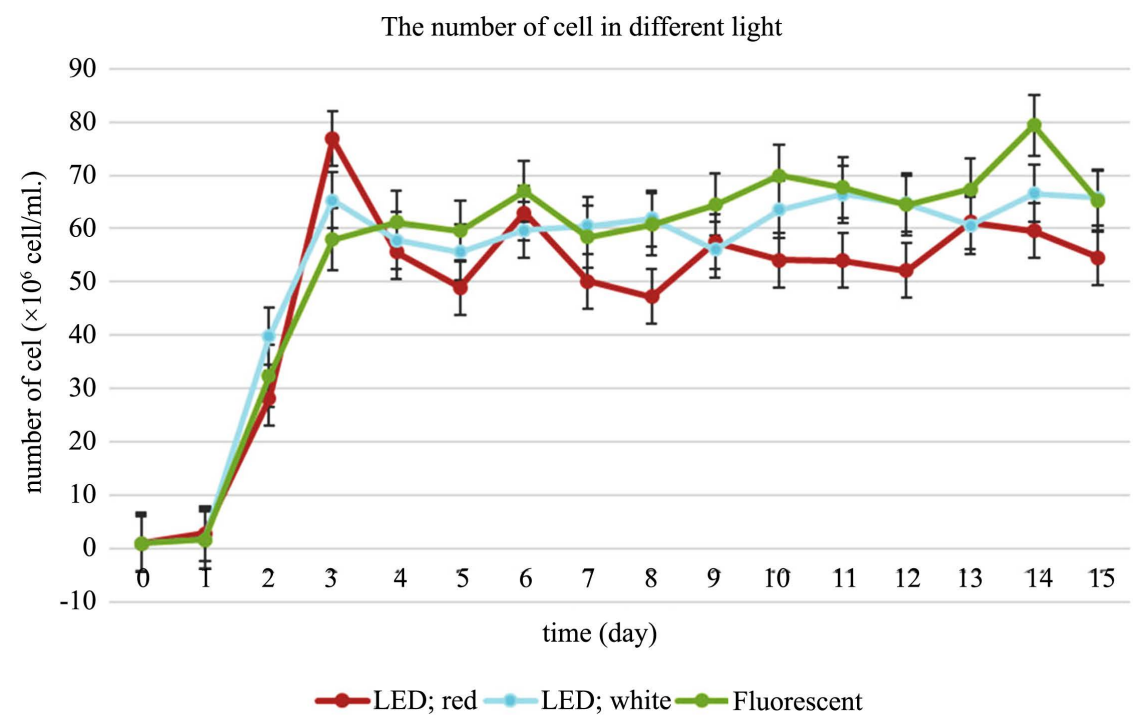

Figure 6. The graph between the density of $C$. vulgaris cell and time using different light sources, 4000 lux, $12 \mathrm{hr}: 12 \mathrm{hr}$ L/D cycle, $0.4 \mathrm{vvm}$ air flow rate, with temperature $28^{\circ} \mathrm{C} \pm$ $2^{\circ} \mathrm{C}$.

Figure 7 shows the variation in growth rate of different algae species with their irradiance levels, where the growth rate of only $N$. incerta was studied in presence of the white and blue light. The maximum growth rate of $P$. globasa was obtained at an irradiance level (white light) of $150 \mathrm{mmol} \cdot \mathrm{m}^{-2} \cdot \mathrm{s}^{-1}$ among the algae species as reported by Sing et al. [45] in their review article. The minimum growth rate of $N$. incerta was reported at an irradiance level (blue light) of 150 $\mathrm{mmol} \cdot \mathrm{m}^{-2} \cdot \mathrm{s}^{-1}$.

Very recently, Esteve et al. [46] conducted an experiment with LEDs with different wavelengths: $380 \pm 750 \mathrm{~nm}$ (white), $620 \pm 750 \mathrm{~nm}$ (red) and $450 \pm 495 \mathrm{~nm}$ (blue). They reported that the maximum specific growth rate was obtained by $N$. oleoabundans with white LEDs $\left(0.264 \pm 0.005 \mathrm{~d}^{-1}\right)$, whereas the maximum biomass productivity $\left(14 \pm 4 \mathrm{mg}_{\mathrm{dw}} \mathrm{L}^{-1} \cdot \mathrm{d}^{-1}\right)$ and $\mathrm{CO}_{2}$ fixation rate $\left(11.4 \mathrm{mg}_{\mathrm{CO} 2}\right.$ $\mathrm{L}^{-1} \cdot \mathrm{d}^{-1}$ ) were obtained by $C$. vulgaris (also with white LEDs). Sometimes, combination of different wavelengths yields maximum growth. This is justified by $\mathrm{Fu}$ et al. [47], who demonstrated that Dunaliella salina obtained the highest production of biomass and carotenoids ( $\beta$-carotene and lutein) with the combined use of $75 \%$ of red light (wavelength around $700 \mathrm{~nm}$ ) and $25 \%$ of blue light (wavelength around $400 \mathrm{~nm}$ ), compared to just the red light.

Metsoviti et al. [48] conducted an experiment on the effect of solar irradiance on $C$. vulgaris cultivated in open bioreactors under greenhouse and they found that the increase in solar irradiance led to faster growth rates of $C$. vulgaris under both environmental conditions studied in the greenhouse (in June up to 0.33 $\mathrm{d}^{-1}$ and in September up to $0.29 \mathrm{~d}^{-1}$ ) and higher lipid content in microalgal biomass (in June up to $25.6 \%$ and in September up to $24.7 \%$ ). They have also examined the ratio of light intensity in the $420-520 \mathrm{~nm}$ range to light in the 580 $680 \mathrm{~nm}$ range $\left(\mathrm{I}_{420-520} / \mathrm{I}_{580-680}\right)$ and of artificial irradiation provided by red and 


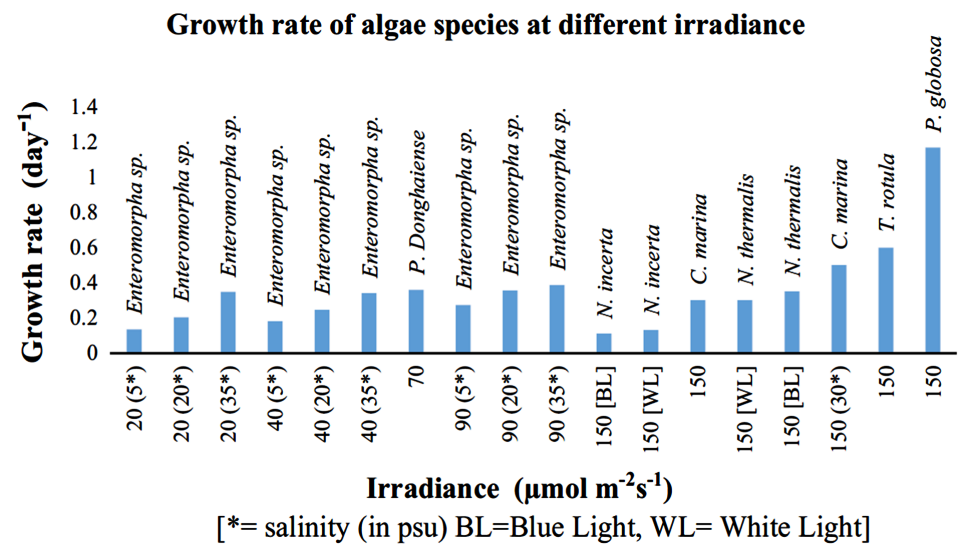

Figure 7. The Growth rate of algae species at different irradiance.

white LED lamps in a closed flat plate laboratory bioreactor on the growth rate and composition. In the experiments conducted in the closed bioreactor, the increase of $\mathrm{I}_{420-520} / \mathrm{I}_{580-680}$ ratio results an increase in the specific growth rate and the biomass, protein and lipid productivities as well. Additionally, the increase in light intensity with red and white LED lamps resulted in faster growth rates (up to $0.36 \mathrm{~d}^{-1}$ ) and higher lipid content (up to $22.2 \%$ ), while the protein, fiber, ash and moisture content remained relatively constant. Overall, the trend in biomass, lipid, and protein productivities as a function of the light intensity was similar in the two systems (greenhouse and bioreactor).

Generally, if the light intensity increases, the microalgal growth also increases up to a photoinhibitory threshold, but it varies among species [49] [50]. Like cell growth, microalgal lipid production is also influenced by the light intensity and it is of particular interest because lipids are the sources of biodiesel. However, increases in light intensity promote or have no effect on lipid production of some species [51] [52], but reduce lipid contents in others [53]. Therefore, studies on the effects of light intensity on lipid production are very important on a species-by-species basis. Lipids, carbohydrates, and proteins are the main ingredients of microalgae [54]. Therefore, if lipid contents increase in a cell, carbohydrates, proteins, or both automatically decrease. An increase in lipids and a decrease in carbohydrate content are often reported due to the nitrogen starvation [55] [56] [57]. Apart from the variable effects on lipid production mentioned above, little is known about how light intensity affects the biochemical composition of microalgae. Therefore, to optimize microalgal lipid production to generate biodiesel, it is important to determine how the production of all three biochemical components changes with light intensity.

To optimize the light intensity for microalgal growth and lipid content various statistical methods have been used by researchers. For instance, the effect of light intensity on Ettlia sp. was studied by Kim et al. [58] and by conducting tests using response surface methodology with Central Composite Face-centered (CCF) design, they found the optimal light intensity of $730 \mu \mathrm{E} \cdot \mathrm{m}^{-2} \cdot \mathrm{s}^{-1}$ where the maximum biomass productivity was reported as $28 \pm 1.5 \mathrm{gm}^{-2} \cdot \mathrm{d}^{-1}$. However, maxi- 
mum lipid productivity was obtained at $500 \mu \mathrm{E} \cdot \mathrm{m}^{-2} \cdot \mathrm{s}^{-1}$, which was reported as $4.2 \pm 0.3 \mathrm{gm}^{-2} \cdot \mathrm{d}^{-1}$. Table 1 shows the optimal light intensity for different microalgae species [37].

An increase of lipid production has been reported by $S$. abundans by increasing the light intensity from 55 to $110 \mu \mathrm{E} \cdot \mathrm{m}^{-2} \cdot \mathrm{s}^{-1}$ [59]. Similarly, several Chlorella species reportedly produce more lipids at a high light intensity $\left(600 \mu \mathrm{E} \cdot \mathrm{m}^{-2} \cdot \mathrm{s}^{-1}\right)$ than at lower light intensities [60]. For instance, high biomass and lipid content of $20 \mu \mathrm{E} \cdot \mathrm{m}^{-2} \cdot \mathrm{s}^{-1}$ was reported by the species $C$. vulgaris [61]. This may be possible at least partly because at high light intensities algae counter photo-oxidation by converting excess photo assimilates into fatty acids [62]. However, some recent studies have found that at high light intensity, lipid contents of various microalgae, including marine strains of Chlorella, reduced despite increasing their biomass, which suggest that instead of being stored in the form of lipids, the energy produced was used for cell division [53] [63]. Recently, Nzayisenga et al. [64] also found that $C$. vulgaris and E. pseudoalveolaris had lower lipid contents when grown at $300 \mu \mathrm{E} \cdot \mathrm{m}^{-2} \cdot \mathrm{s}^{-1}$ light than that at lower light intensities, despite increases in biomass (Figure 8). Studying with two more species with the highest biomass yields for 15 days, they reported that during the period between 8 and 15 days, fatty acid contents of $S$. obliquus growing at $300 \mu \mathrm{E} \cdot \mathrm{m}^{-2} \cdot \mathrm{s}^{-1}$ light doubled, from $5.8 \%$ to $11.6 \%$, but changed little at the 50 and $150 \mu \mathrm{E} \cdot \mathrm{m}^{-2} \cdot \mathrm{s}^{-1}$ light intensities (Figure 8). In contrast, fatty acid contents of Desmodesmus sp. slightly increased during this period under all light intensities. It has been recommended that increases in lipid production under high light intensities may be

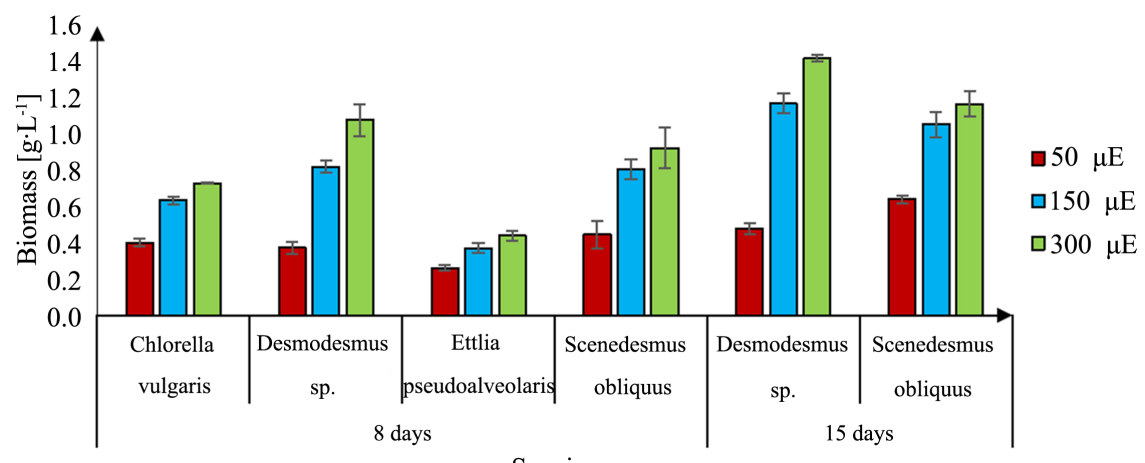

Figure 8. Biomass of the four microalgal strains after growth for indicated times under indicated light intensities: mean \pm standard deviation $(n=3$ from three separate experiments).

Table 1. Optimal light intensity for different microalgae species.

\begin{tabular}{cc}
\hline Microalgae species & Optimal average light irradiance $\left(\mu \mathrm{E} \cdot \mathrm{m}^{-2} \cdot \mathrm{s}^{-1}\right)$ \\
\hline C. vulgaris & 208 \\
P. subcapitata & 258 \\
M. aeruginosa & 140 \\
M. aeruginosa & 178 \\
\hline
\end{tabular}


partly caused by starvation [65]. However, the fatty acid contents of Desmodesmus sp. and $S$. obliquus (grown for either 8 or 15 days) increased with the increases in the light intensity, their protein contents declined, and no significant change observed in their carbohydrate contents [64]. Similarly, reductions in protein contents and increases in lipid contents of Dunaliella tertiolecta associated with increases in light intensity have been observed [66]. Their current results also show that higher lipid content is linked to lower protein content, suggesting that lipid synthesis relied mostly on protein degradation or inhibition of protein synthesis [64]. This is also supported by He et al. [67], which showed that decrease of protein content under increasing light intensity may be attributed to the consumption of nitrogen. Thus, it is possible that microalgae may have different mechanisms to synthesize fatty acids under high light intensities and/or nutrient starvation, which could affect either protein or carbohydrate content.

In most production systems, as soon as a high cell concentration is reached, the proportion of light zones to dark zones becomes too low and the retention time of cells in the dark area becomes too long, which increases respiration, leading to biomass losses [68]. To avoid photo limitation and maximize the growth, flashing (or pulsed-) light emitting diodes (LEDs) are used recently to generate high-light flashes artificially, which penetrate deep into the culture [69] [70]. The potential benefits of flashing light reported in previous studies differed considerably, and they usually focused on flashing conditions of low frequencies $(f<100 \mathrm{~Hz})$ and relatively high duty cycles $(D C>0.1)$ that were used to mimic light regimes in mixed cultures [28] [68]. It was uncertain if flashing light of high frequencies and short duty cycles (e.g., $f>100 \mathrm{~Hz}, D C<0.1$ ) can indeed improve microalgae growth performance. In Schulze et al. [70], they reviewed the potential of flashing light to improve microalgal growth and suggested a minimum theoretical frequency threshold of $200-333 \mathrm{~Hz}$ which is necessary to obtain the biological flashing light effect in microalgae. Very recently, Schulze et al. [71] performed another experiment on flashing light applied to Chlorella stigmatophora and Tetraselmis chui and they have concluded that artificial flashing light does not improve microalgal biomass productivities in photobioreactor, but low frequencies $(f<50 \mathrm{~Hz})$ may be still used to improve light harvesting-associated biomolecules production. Similarly, several studies have reported the importance of light intensity on microalgal growth substantiating the increase of biomass concentration under optimal light conditions [72] [73] [74].

\subsection{Temperature}

Temperature is considered as one of the most significant environmental factors that influence algal growth rate, cell size, biochemical composition and nutrient requirements. Microalgae cultures absorb heat by radiation from the light source used resulting the increase of temperature in the culture. Thus, for a large scale 
outdoor culture the irradiance of sunlight and associated temperature is also needed to consider [75]. The optimal temperature for microalgae growth ranges from $20^{\circ} \mathrm{C}$ to $35^{\circ} \mathrm{C}$, although some mesophilic species can endure up to $40^{\circ} \mathrm{C}$. Below the optimal temperature the yield of the strain gets reduced, but overheating of the cultures has been identified as critical since it can damage the cells [76]. Therefore, seasonal variations, which lead to the temperature variations during the day/night cycle, have significant effects on microalgal cultivation.

The optimal temperature for $S$. almeriensis is $35^{\circ} \mathrm{C}$, but the cultures die at temperatures higher than $45^{\circ} \mathrm{C}$ (Figure 9) [77]. In case of small-scale reactors, no temperature control is required because the input of heat by radiation is compensated by the output by convection if the air surrounding system is cold enough. However, in outdoor large-scale reactors the solar radiation is high, and additional heat control systems must be used to avoid overheating [78] [79]. Thus, a cost-effective cooling system set-up is necessary for better performance of the PBR.

To prevent overheating of the microalgae cultivation several methods have been tested by researchers. Among them are as follows: 1) using shades with dark-colored sheets [80], 2) cooling by spraying water on the surface of the photobioreactor [81], 3) submerging the entire culture or part of the photobioreactor in a large amount of water [81], and 4) installing a heat exchanger for the photobioreactor [82]. However, shading the PBR greatly reduces the illumination and consequently in the yield of biomass and thus it is inefficient. Though water spraying is one of the most common methods and efficient for cooling, it is only useful in locations with low air humidity and it also increases cultivation costs. On the other hand, controlling temperature by the method of submersion has been demonstrated to promote the average light intensity in the culture.

Several studies have been performed by researchers to show that the temperature has a positive impact on biomass and lipid yield of microalgae [83] [84] [85]. For instance, maximum lipid productivity of $274.15 \mathrm{mgL}^{-1} \cdot \mathrm{d}^{-1}$ was observed under optimal temperature and $\mathrm{pH}$ at $28.63^{\circ} \mathrm{C}$ and 6.51 respectively for

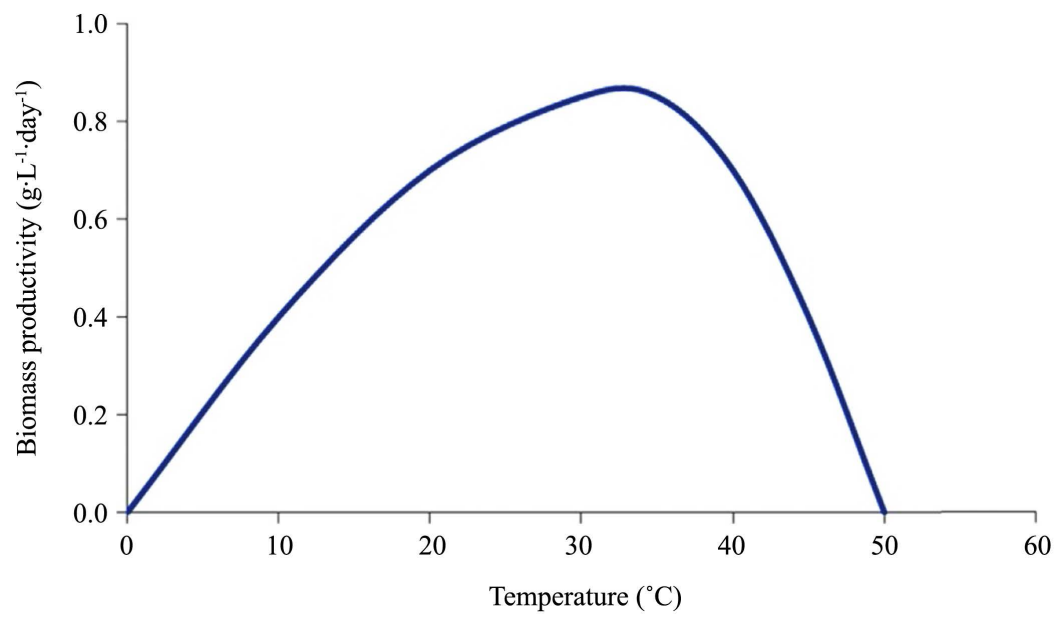

Figure 9. Influence of the temperature in the biomass productivity of Scenedesmus almeriensis in continuous cultures at laboratory conditions. 
Chlorella protothecoides, which was statistically proven by response surface methodology using Box-Behnken design with smaller $\mathrm{p}$-value $(\mathrm{p}<0.001)$ indicating its significance [86]. Gonçalves et al. [37] evaluated the effect of temperature on the growth of microalgae (C. vulgaris, P. subcapitata, Synechocystis salina and Microcystis aeruginosa) and nutrients uptake. In the case of $C$. vulgaris, these authors found that the optimum temperature for growth was $25^{\circ} \mathrm{C}$. According to study conducted by Singh et al. [45] some species such as Chlorella, Nannochloropsis, Neochloris, Scenedesmus, Spirogyra, Chlamydomonas, Botrycoccus, Haematococcus, Ulva species, few red algae, brown algae and blue-green algae can grow in a temperature range of $20^{\circ} \mathrm{C}-30^{\circ} \mathrm{C}$ with the light intensity in the range of $33-400 \mu \mathrm{E} \cdot \mathrm{m}^{-2} \cdot \mathrm{s}^{-1}$ [87]. It was observed that at the optimal temperature of $25^{\circ} \mathrm{C}$ and $20^{\circ} \mathrm{C}$ for Nannochloropsis occulata and Tetraselmis subcordiformis respectively, the growth rate was higher whereas the neutral lipid concentration was found to be at higher level under $15^{\circ} \mathrm{C}$ and $20^{\circ} \mathrm{C}$ for T. subcordiformis and N. occulata respectively [88]. It is also reported that, at high temperature the cell metabolism disrupts and stop the cell production through enzyme damage [89].

\subsection{Nutrients}

Conditions of nutrient limitation affect a considerable variation in the biochemical composition of microalgae. An ideal culture medium for microalgae must contain inorganic elements such as Phosphorus (P), Nitrogen $(\mathrm{N})$, and Iron $(\mathrm{Fe})$, among others, which may vary according to the cultivated species. The minimum nutritional requirements needed for the growth of microalgae can be determined by the approximate molecular formula $\mathrm{CO}_{0.48} \mathrm{H}_{1.83} \mathrm{~N}_{0.11} \mathrm{P}_{0.01}$ [31]. Thus, the most important nutrients or macronutrients for autotrophic growth are the carbon (C), nitrogen (N) and phosphorus (P) [26]. According to the molecular formula of biomass, it is reasonable to say that about $50 \%$ of the biomass is composed of carbon (C) [31]. Carbon is needed in high concentrations, since it is the vital constituent of all organic substances synthesized by the cells, such as carbohydrates, proteins, nucleic acids, vitamins and lipids [26]. Microalgae have inorganic carbon assimilation processes: diffusion $(5.0<\mathrm{pH}<7.0)$ and active transport $(\mathrm{pH}>7.0)$ [90]. $\mathrm{CO}_{2}$ and bicarbonates $\left(\mathrm{HCO}_{3}^{-}\right)$supply are very important in order to achieve high autotrophic production rates [26]. Organic compounds (e.g. sugars, acids and alcohols) can also be used as carbon source for certain species of microalgae that grow in mixotrophic conditions.

Nitrogen is a vital element of structural and operating proteins, the most important element after carbon [81]. It is the second most abundant element in microalgal biomass containing $1 \%$ to $14 \%$ concentration in dry mass. It is responsible for the formation of proteins, nucleic acids, vitamins and photosynthetic pigments [26]. The assimilation mechanism of nitrate and ammonium $\left(\mathrm{NH}_{4}^{+}\right.$) by microalgae is active transport [90]. Nitrogen is mainly provided as $\mathrm{N}_{2}$ and in some cases, in the inorganic forms $\mathrm{NO}_{3}^{-}, \mathrm{NO}_{2}^{-}, \mathrm{NO}, \mathrm{NH}_{4}^{+}$, or in the 
organic form, through urea or amino acids [91]. Silva et al. [92] evaluated the preferred source of nitrogen $\left(\mathrm{NO}_{3}^{-}\right.$and $\mathrm{NH}_{4}^{+}$) for two species of microalgae (Chlorella vulgaris and Pseudokirchneriella subcapitata) and they concluded that the ammonium $\left(\mathrm{NH}_{4}^{+}\right)$was preferred source of nitrogen for microalgae $C$. vulgaris, since its assimilation by the microalgae involves lower energy consumption [93]. Microalgal growth rate is nearly identical depending on the nitrogen sources used (urea, nitrite, and nitrate). Deficit of nitrogen concentration in the cultivation allows lipids and carbohydrates to be synthesized preferentially [94]. When the microalgae suffer nitrogen shortage, a discoloration of the cells usually occurs (reduction of chlorophylls and carotenoids increase) and a build-up of organic compounds such as polysaccharides and some oils [81]. Goiris et al. [95] studied the impact of nutrient limitation in the production of antioxidants in three species of microalgae (Phaeodactylum tricornutum, Tetraselmis suecica and $C$. vulgaris) and they observed the content of chlorophyll a in biomass was significantly lower when the microalgae were limited by nitrogen.

Phosphorus is another essential nutrient for growth and for many cellular metabolic activities, such as energy transfer, synthesis of nucleic acids, deoxyribonucleic acid (DNA), among others [26]. The concentration of phosphorus can range from $0.05 \%$ to $3.3 \%$ in dry mass [96]. In wastewater, as well as in natural environments, phosphorus is present in various forms, such as polyphosphate, pyrophosphate, orthophosphate, and metaphosphate [97]. Like nitrogen, phosphorus is also assimilated by the microalgae through active transport [90]. Absorption of this chemical element is energy dependent and it is preferentially added in the form of orthophosphate $\left(\mathrm{PO}_{4}^{3-}\right)$ [26]. The composition of biomass production is also influenced by the supply of phosphorus [98]. Internal and external phosphorus supply affects lipids and carbohydrates contents. Moreover, the N: P ratio in the culture medium is also important, as it influences not only the productivity, but also the dominant species in culture [26]. The N: P ratio of 16:1 was first estimated by Alfred C. Redfield in 1934 through the elemental composition of microalgal cells. This ratio is known as Redfield ratio after his name. However, several studies have tested different ratios [99] [100] [101] [102]. Silva et al. [92] evaluated the effect of N:P ratio on the growth of microalgae $C$. vulgaris and $P$. subcapitata and the N: P ratios of 8:1, 16:1 and 24:1 were evaluated. For $C$. vulgaris, the N: $\mathrm{P}$ ratio of 8:1 was the one that more favored the growth. Reduction of phosphorus may cause pigment accumulation in some microalgae, but the impact is lower than the nitrogen deficiency [81]. Its absent or present at low concentrations can be limiting or affecting the biomass productivity of several microalgae species [103]. Microalgae can amass intracellular reserves of phosphorus, which can be used when phosphate is exhausted in the medium, a behavior known as luxury uptake or accumulation [104]. When the objective is to remove phosphorus from wastewater, it can be used; however, in cultures where synthetic fertilizers are used, luxury uptake should be avoided to maximize the biomass production per mass of nutrients added [97]. 
Besides the macronutrients already mentioned (nitrogen, phosphorus and potassium), for the adequate growth of microalgae, the medium should contain other nutrients (micronutrients) too. The essential micronutrients are $\mathrm{Mg}, \mathrm{S}, \mathrm{Na}$, $\mathrm{Cl}, \mathrm{Ca}, \mathrm{Fe}, \mathrm{Mo}, \mathrm{Mn}, \mathrm{Zn}, \mathrm{Cu}, \mathrm{B}$ and $\mathrm{Co}$, with prominence on magnesium, sulfur and iron (Mg, $\mathrm{S}$ and $\mathrm{Fe}$, respectively). Iron is an essential trace element for microalgae growth because of its involvement in the transport of electrons in the process of photosynthesis [105]. Most of these micronutrients can be found in both wastewater and seawater [106]. Fertilizers and salts can also be used as sources of these micronutrients [97].

Table 2 depicts how addition of nutrients increases biomass production and shortens the time of cultivation. The cultivation of Chlamydomonas sp. in a Tubular PBR, in Run-1, the time was required for microalgae cultivation (10 days) was longer than Run- 4 which only takes 7 days, so that, the growth rate in Run-4 was greater than Run-1. Microalgae obtain foods from the addition of nutrients to support their growth, thus shortening the time of cultivation [107].

\subsection{Carbon Dioxide $\left(\mathrm{CO}_{2}\right)$}

Carbon dioxide $\left(\mathrm{CO}_{2}\right)$ is another important factor that involved in the growth of microalgae production. To produce $1 \mathrm{~kg}$ of biomass, microalgae require from 1.8 to $2.0 \mathrm{~kg}$ of $\mathrm{CO}_{2}$ [31]. Considering this ratio, the amount of $\mathrm{CO}_{2}$ present in the air $(0.03 \%)$ is not enough to provide the necessary gas pressure in the culture to promote high productivity. Thus, for increasing photosynthetic efficiency in their growth, it is necessary to supply carbon, either in the form of salts, such as bicarbonate, or by injection of $\mathrm{CO}_{2}$-rich air in the culture [108] [109]. Dúran et al. [110] demonstrated that using air injection $\left(600 \mathrm{~mL} \cdot \mathrm{min}^{-1}\right)$ in a photobioreactor, microalgae showed optimal growth with up to $20 \%$ (volume per volume) of $\mathrm{CO}_{2}$ present in the injected air, not differing much from the optimal value for microalgae growth. This creates the possibility of using $\mathrm{CO}_{2}$ from industrial burning; a process that generates on average 5.0\% (volume per volume) of $\mathrm{CO}_{2}$, and depending on the technology and type of fuel used, this concentration may reach up to $20 \%$ [111]. This use combines a low-cost source of carbon for microalgae with the reduction of $\mathrm{CO}_{2}$ emissions to the atmosphere. The supply of $\mathrm{CO}_{2}$ to microalgae cultures allows increasing biomass productivity, but the reduction of $\mathrm{pH}$, which can inhibit the growth of some species of these microorganisms [112].

Table 2. The effect of adding nutrients against time of cultivation and the microalgae growth rate $(\mu) /$ day.

\begin{tabular}{ccc}
\hline Parameter & $\begin{array}{c}\text { Without nutrient } \\
(\text { Run- })\end{array}$ & $\begin{array}{c}\text { Addition of nutrient } \\
\text { (Run-4) }\end{array}$ \\
\hline Cultivation time & 10 days & 7 days \\
Growth rate $(\mu) /$ day $(\mathrm{Q}=0.071 \mathrm{~L} / \mathrm{min})$ & 0.16 & 0.33 \\
Biomass production $\left(\mathrm{gr} / \mathrm{dm}^{3}\right)$ & 4.892 & 5.684 \\
\hline
\end{tabular}


For optimizing $\mathrm{CO}_{2}$ concentration in Ettlia sp. to produce maximum biomass and lipid concentration an experiment has been done by Kim et al. [58] using response surface methodology with Central Composite Face-centered (CCF) design and they have found $8 \% \mathrm{CO}_{2}$ and $7 \% \mathrm{CO}_{2}$ as optimal concentration for maximum biomass $\left(28 \pm 1.5 \mathrm{~g} \cdot \mathrm{m}^{-2} \cdot \mathrm{d}^{-1}\right)$ and lipid $\left(4.2 \pm 0.3 \mathrm{~g} \cdot \mathrm{m}^{-2} \cdot \mathrm{d}^{-1}\right)$ productivity respectively. The optimal concentration of $\mathrm{CO}_{2}$ was found to be $6.5 \%$ for Chlorella vulgaris which was statistically determined through response surface methodology with Central Composite Design (CCD) having $\mathrm{R}_{2}>0.90$ [113]. However, maximum specific growth rate of $0.310 \mathrm{~d}^{-1}$ was reported in a study conducted by Kasiri et al. [114] at $22 \% \mathrm{CO}_{2}$ concentration whereas at $35 \% \mathrm{CO}_{2}$ concentration, maximum $\mathrm{CO}_{2}$ uptake rate of $63.03 \mathrm{mg} \cdot \mathrm{L}^{-1} \cdot \mathrm{d}^{-1}$ was observed for Chlorella kessleri.

Hadiyanto et al. [107] studied the growth rate of Chlamydomonas sp. compared with the productivity in terms of carbon dioxide flow rate, as shown in Figure 10. It shows that in the variation of $10 \%$ and $20 \%(\% \mathrm{v}) \mathrm{CO}_{2}$ concentration, both growth rate and biomass productivity increase. However, in the variation of $30 \%$ and $40 \%$ (\% v) $\mathrm{CO}_{2}$ concentration, either growth rate and biomass productivity begin a constant. This shows that bicarbonate ion $\left(\mathrm{HCO}_{3}^{-}\right)$at $10 \%$ and $20 \%(\% \mathrm{v})$ concentration, still be converted into biomass by the culture with the help of Carbonic Anhydrate (CA), while the $30 \%$ and $40 \%$ (\% v) $\mathrm{CO}_{2}$ concentration, $\mathrm{CA}$ began to saturate so that the efficiency of CA, in the use of bicarbonate ion, start to decrease.

\subsection{Hydrogen Potential (pH) and Salinity}

The $\mathrm{pH}$ has great significance in microalgal cultures, because, besides affecting the microalgae themselves, it determines the solubility of minerals and $\mathrm{CO}_{2}$ in the medium [115]. Several factors such as composition and buffering capacity,

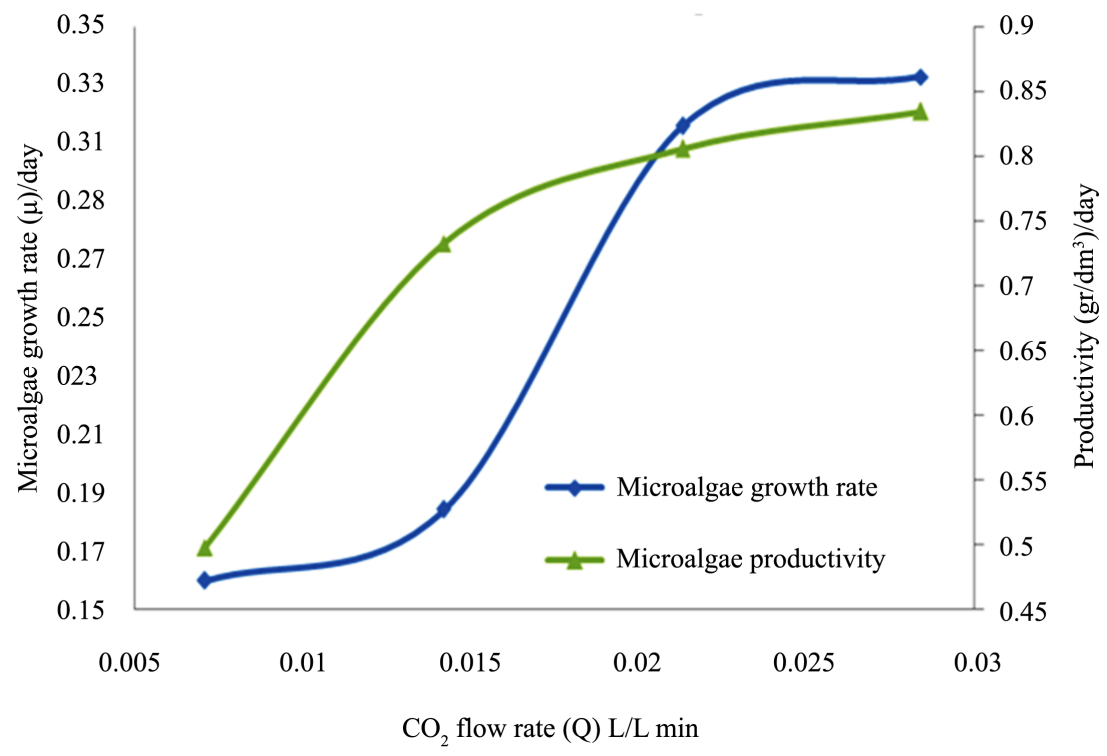

Figure 10. Growth rate and productivity of microalgae. 
amount of dissolved $\mathrm{CO}_{2}$, temperature and metabolic activity of the cells may influence the $\mathrm{pH}$ of the culture medium [116]. Levels of tolerance to the $\mathrm{pH}$ of the culture medium vary species to species, which may affect the growth rate, but the most common $\mathrm{pH}$ values for microalgae culture vary from 6 to 8 [27] [117]. Most microalgae usually tolerate wide $\mathrm{pH}$ intervals, but beyond this interval the yield is greatly reduced. Optimal $\mathrm{pH}$ values for microalgae range from neutral to slightly alkaline (7.0 - 10.0), although some species have optimal $\mathrm{pH}$ at acidic values below 3.0 [118] [119]. The optimal $\mathrm{pH}$ ranges from 7.5 to 8.5 and the biomass productivity is strongly decreasing at $\mathrm{pH}$ above 9.0 in the case of Scenedesmus almeriensis (Figure 11) [77].

The hydroxide ion $\left(\mathrm{OH}^{-}\right)$accumulates in the growing medium, leading to a gradual increase of $\mathrm{pH}$ during the photosynthetic $\mathrm{CO}_{2}$ fixation [26]. This shifts the chemical equilibrium of the inorganic carbon present in the medium towards the formation of carbonates $\left(\mathrm{CO}_{3}^{2-}\right)$. However, they are not the preferred carbon source for microalgae [120]. On the other hand, a decrease of solution $\mathrm{pH}$ moves the chemical equilibrium towards the formation of $\mathrm{CO}_{2}$, which is considered one of the preferred carbon sources for microalgae. Nevertheless, this process can lead to the release of $\mathrm{CO}_{2}$ into the atmosphere, decreasing the concentration of this nutrient extremely important for the cultivation of microalgae.

Addition of nitrogen to the culture also influences the $\mathrm{pH}$. When nitrogen is provided in the form of ammonium, the solution $\mathrm{pH}$ increases by decreasing the concentration of nitrogen available for microalgae [121] [122]. High $\mathrm{pH}$ values shift the chemical equilibrium of ammonium for the production of ammonia which can be released into the atmosphere due to the aeration of the culture, reducing nitrogen availability for microalgae.

The concentration of phosphorus in culture medium can also be influenced by elevated $\mathrm{pH}$, as it can lead to precipitation of phosphate (in the forms of calcium phosphate, iron phosphate and aluminium phosphate) and therefore limit the amount of phosphorus available for microalgae [122] [123].

The $\mathrm{pH}$ can directly affect the microalgae, as the $\mathrm{pH}$ of microalgal cytoplasm is neutral or slightly alkaline, and enzymes are $\mathrm{pH}$-sensitive and may be inactive

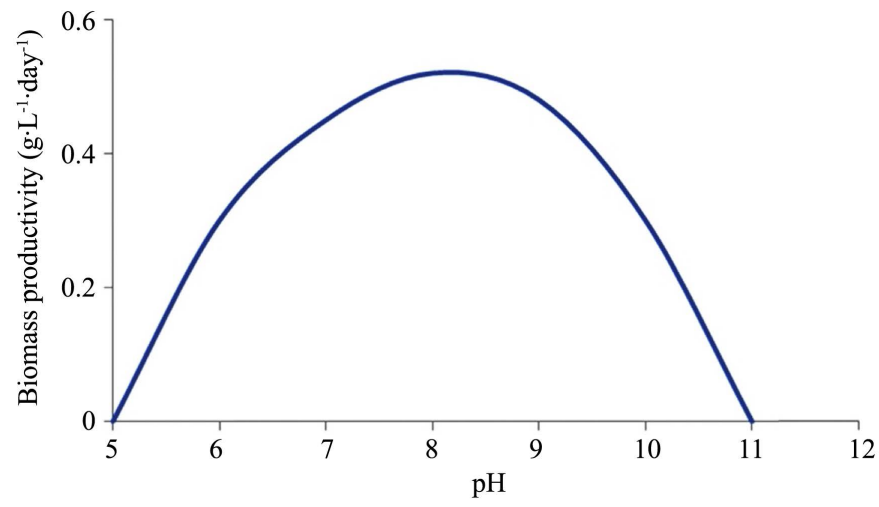

Figure 11. Influence of $\mathrm{pH}$ in the biomass productivity of Scenedesmus almeriensis in continuous cultures at laboratory conditions. 
in acidic conditions [124]. Therefore, extreme $\mathrm{pH}$ conditions can cause the disruption of many cellular processes, which may lead to the collapse of culture [93].

Tripathi et al. [125] studied the effect of $\mathrm{pH}$ on the growth of Scenedesmus sp. in a $\mathrm{pH}$ range from 7 to 10 and concluded that the optimal $\mathrm{pH}$ for this species was 8. Munir et al. [126] examined the $\mathrm{pH}$ effect on the growth of two microalgae species (Spirogyra sp. and Oedogonium sp.) in a range of 6.5 - 9.0, achieving the highest growth at $\mathrm{pH} 7.5$ for both species. Wu et al. [127] studied the effect of $\mathrm{pH}$ on the growth of Scenedesmus sp. LX1. by varying the $\mathrm{pH}$ from 5 to 11 and observed that, for $\mathrm{pH}$ values of 7, 9 and 11, there was no significant difference of growth in the cultures. However, there was a significant limitation in the growth of the microalgae at $\mathrm{pH} 5$.

The variation of $\mathrm{pH}$ can be reduced by using buffers in the cultures, but for large-scale systems, it is costly. As $\mathrm{CO}_{2}$, when dissolved, reduces the $\mathrm{pH}$ of the medium, pumping atmospheric air $\left(0.03 \%\right.$ of $\left.\mathrm{CO}_{2}\right)$ or $\mathrm{CO}_{2}$-enriched air through the aeration of the cultures can regulate $\mathrm{pH}$ variation in the culture [128].

Figure 12 shows the growth curves of Chlorella sorokiniana DOE1412 and $\mathrm{CO}_{2}$ addition during PBR cultivation at different $\mathrm{pH}$ values. Data are the average

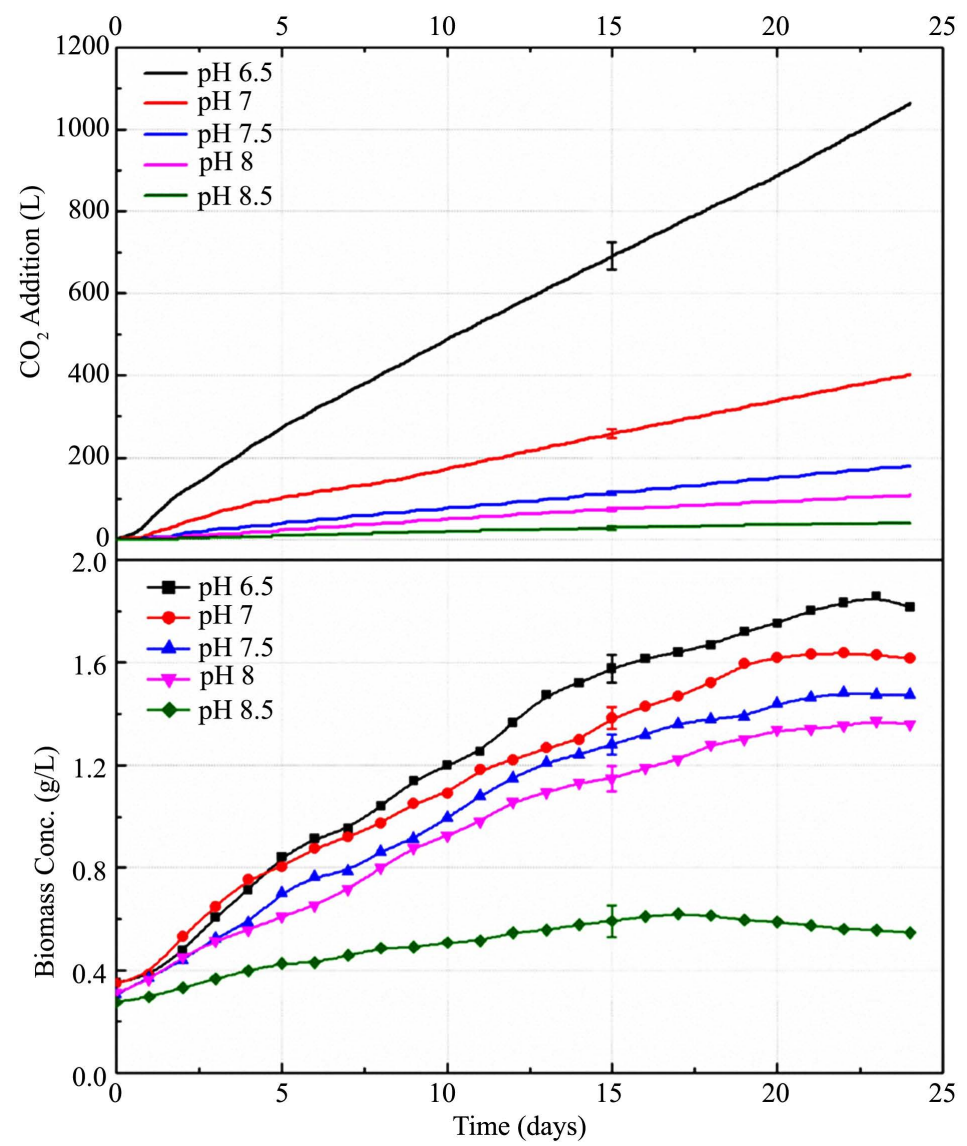

Figure 12. Growth curves for Chlorella sorokiniana DOE1412 and $\mathrm{CO}_{2}$ addition for cultures at different $\mathrm{pH}$ in a $90 \mathrm{~L}$ PBR. Data are the average of duplicates. \pm S.D. lines at $\mathrm{t}=$ 15 day are shown. 
of duplicates. DOE1412 exhibited a longer linear growth phase with lower growth rates in these larger reactors, which were light limited. The linear growth rates calculated using the first ten days of data were $0.091 \mathrm{~g} / \mathrm{L}$-day for $\mathrm{pH} 6.5$, $0.074 \mathrm{~g} / \mathrm{L}$-day for $\mathrm{pH} 7,0.068 \mathrm{~g} / \mathrm{L}$-day for $\mathrm{pH} 7.5,0.061 \mathrm{~g} / \mathrm{L}$-day for $\mathrm{pH}$ 8, and $0.023 \mathrm{~g} / \mathrm{L}$-day for $\mathrm{pH}$ 8.5. Biomass growth rates decreased with increasing $\mathrm{pH}$ from 6.5 to 8.5 , with a significant drop in rate at a $\mathrm{pH}$ of 8.5 (about a quarter of the rate at $\mathrm{pH}$ 6.5) [115]. However, the lipid content was not a function of $\mathrm{pH}$ in the PBRs as no significant differences were found (See Figure 13 oneway ANOVA: $p$ > 0.05). Overall, the lipid content was slightly lower at the larger scale ( $25.7 \%$ by mass), which is often observed. These values were similar to the observations of Moheimani [129].

Salinity is another factor that requires attention, during microalgae cultivation because in open culture it tends to increase due to the intense evaporation, increasing their concentration in the medium. Some species of microalgae, especially those found in freshwater environments, are very restricted in terms of salinity. In general, based on their tolerance to salinity microalgae can be divided into three categories: oligohaline, when they can develop only in water with low salinity (maximum salinity between 0.5 and $5 \mathrm{~g} \cdot \mathrm{kg}^{-1}$ ); mesohaline, when they develop in environments of moderately saline water, with salinity between 5 and $18 \mathrm{~g} \cdot \mathrm{kg}^{-1}$, and polyhaline, when they can develop in highly saline water, with salinity between 18 and $30 \mathrm{~g} \cdot \mathrm{kg}^{-1}$ [130].

\subsection{Mixing}

The mixing plays a key role in the balance of gases and $\mathrm{pH}$ of the system. Sufficient turbulence of microalgae cultures minimizes the existence of gradients that can limit the performance of the cells. Thus mixing reduces the gradient of nutrients in the culture broth, avoids cell sedimentation in the system, and forces the cells to move between dark to light zones, enhancing photosynthesis [131]. It helps to facilitate heat transfer and avoid thermal stratification by ensuring all cells of the population to have uniform average exposure to light and nutrient.

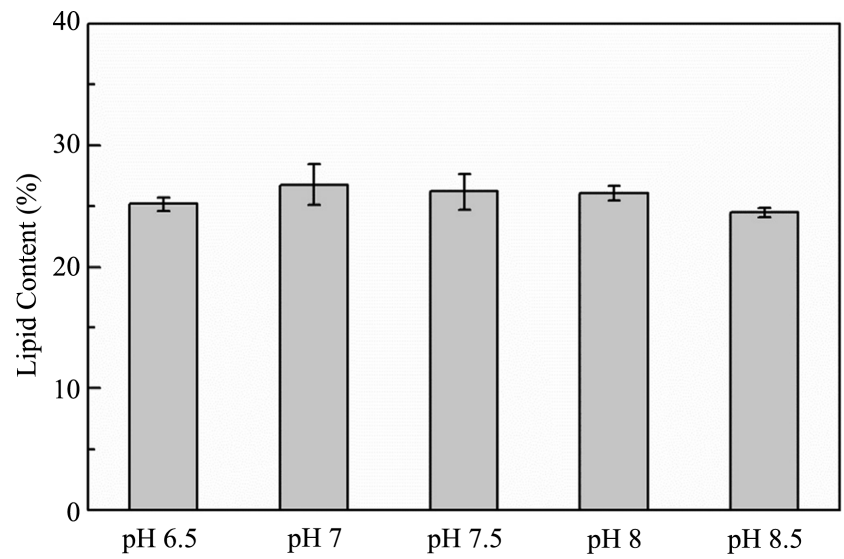

Figure 13. Lipid content for Chlorella sorokiniana DOE1412 grown at different $\mathrm{pH}$ in a 90 L PBR. Data are shown as means \pm S.D., $\mathrm{n}=4$. 
The mixing is usually provided by aeration with $\mathrm{CO}_{2}$-enriched gas bubbles or pumping, mechanical agitation, or a combination of these means in the tubular PBR. Since, some of the species do not tolerate vigorous agitations, so care must be taken in choosing the appropriate system [19] [132]. The energy supplied imposes a cost, whatever the mixing method is, which must be optimized. Furthermore, excessive mixing can damage cells and consequently reduce the growth of the culture. Thus aeration and/or agitation by pneumatic and mechanical devices may produce cell damage if microalgae are susceptible to hydrodynamic and mechanical shear forces, thus impacting culture performance [133] [134]. Main factors determining shear sensitivity are the type of microalgae (the presence of fragile flagellate), composition and thickness of the cell wall, intensity and nature of the shear stress, and adequacy of culture conditions to which the cells are exposed ( $\mathrm{pH}$, temperature, irradiance, etc.) [131]. The shear rates for a single phase flow and multi-phase flow have been thoroughly studied by Deb et al. [135] [136].

In a study conducted by Sánchez et al. [137], it was noticed that in raceway culture systems stirred by paddles, the daily growth of Isochrysis galbana microalgae culture was double when compared to the system without stirring $(8.8 \times$ $10^{5}$ and $4.0 \times 10^{5}$ cells $\left.\mathrm{mL}^{-1} \cdot \mathrm{d}^{-1}\right)$. This shows the importance of stirring the culture medium in the industrial processes of microalgae production.

Sobczuk et al. [138] investigated the mixing effect on biomass concentration for P. tricornutum. Their results are shown in Figure 14. Initially, the biomass concentration remained constant and steady at an agitation speed of $150 \mathrm{rpm}$ (i.e. impeller tip speed of $0.68 \mathrm{~m} \cdot \mathrm{s}^{-1}$ ). After that the agitation rate was increased stepwise from 150 to $550 \mathrm{rpm}$. The biomass concentration changed and attained new steady states for each step change in the agitation rate. The increase in the agitation rate increased the biomass concentration up to a maximum impeller speed of $350 \mathrm{rpm}$ (impeller tip speed of $1.56 \mathrm{~m} \cdot \mathrm{s}^{-1}$ ) even though the dilution rate was held constant at $0.0139 \mathrm{~h}^{-1}$ throughout the experiment. Further increase in the agitation speed declined the biomass concentration, but stable steady states were achieved up to the highest impeller speed investigated.

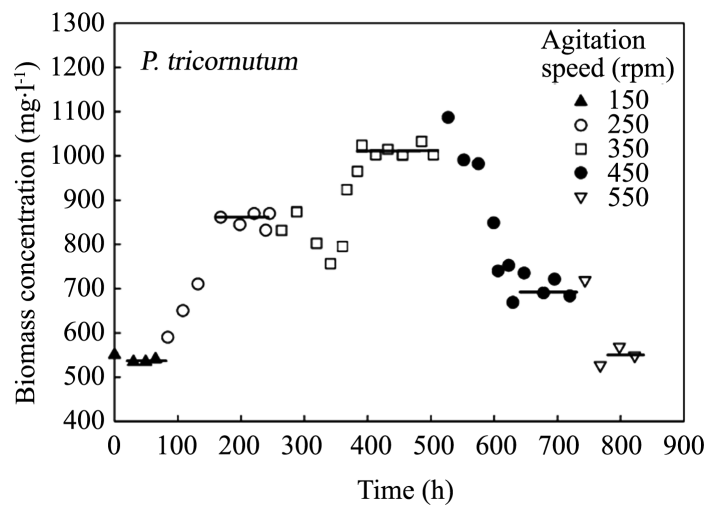

Figure 14. P. tricornutum biomass concentration versus time in the continuous culture at various impeller agitation speeds. Horizontal lines indicate steady states. 


\section{Conclusions}

There is no doubt that microalgae have tremendous potential as a source of biofuel, food, feed and high value bio-compounds. Since they are rich in lipids, proteins, and carbohydrates, which are the sources of many beneficial products for mankind, in the near future, microalgae will generate clean energy and third generation biofuels, thus contributing to sustainable development both environmentally and economically. However, there are still limitations in the productivity of microalgae. Therefore, more researches needed to further improve the existing technology. For instance, more advanced culturing techniques incorporating with novel biotechnology should be developed to increase the productivity of microalgae. As the algal biofuels will play a vital role in future, attention should be given on the following:

- Optimization of the culture growth parameters is necessary for high yields of biomass and lipid content.

- Development of modern technology for large-scale industrial production of biofuels along with wastewater treatment.

- Improvement of the CFD simulations and mathematical modeling-based process, before industrial trial and scale-up.

\section{Conflicts of Interest}

The authors declare no conflicts of interest regarding the publication of this paper.

\section{References}

[1] Harder, R. and von Witsch, H. (1942) Ueber Massenkultur von Diatomeen. Berichte der Deutschen Botanischen Gesellschaft, 60, 14-153.

[2] Chisti, Y. (2016) Large-Scale Production of Algal Biomass: Raceway Ponds. In: Bux, F. and Chisti, Y., Eds., Algae Biotechnology: Products and Processes, Springer, New York, 21-40. https://doi.org/10.1007/978-3-319-12334-9 2

[3] Chew, K.W., Yap, J.Y., Show, P.L., Suan, N.H., Juan, J.C., Ling, T.C., et al. (2017) Microalgae Biorefinery: High Value Products Perspectives. Bioresource Technology, 229, 53-62. https://doi.org/10.1016/j.biortech.2017.01.006

[4] Raslavičius, L., Striūgas, N. and Felneris, M. (2018) New Insights into Algae Factories of the Future. Renewable and Sustainable Energy Reviews, 81, 643-654. https://doi.org/10.1016/j.rser.2017.08.024

[5] Jacob-Lopes, E., Zepka, L.Q., Merida, L.G.R., Maroneze, M.M. and Neves, C. (2014) Bioprocesso de conversão de dióxido de carbono de emissões industriais, bioprodutos, seus usos e fotobiorreator híbrido. BR n. PI2014000333.

[6] Collotta, M., Champagne, P., Busi, L. and Alberti, M. (2017) Comparative LCA of Flocculation for the Harvesting of Microalgae for Biofuels Production. Procedia CIRP, 61, 756760. https://doi.org/10.1016/j.procir.2016.11.146

[7] Chang, J.S., Show, P.L., Ling, T.C., Chen, C.Y., Ho, S.H. and Tan, C.H. (2017) Photo-Bioreactors. In: Larroche, C., Sanroman, M., Du, G. and Pandey, A., Eds., Current Developments in Biotechnology and Bioengineering: Bioprocesses, Bioreactors and Controls, Elsevier, Atlanta, 313-352. 
https://doi.org/10.1016/B978-0-444-63663-8.00011-2

[8] Su, Y., Song, K., Zhang, P., Su, Y., Cheng, J. and Chen, X. (2017) Progress of Microalgae Biofuel's Commercialization. Renewable and Sustainable Energy Reviews, 74, 402-411. https://doi.org/10.1016/j.rser.2016.12.078

[9] Lundquist, T.J., Woertz, I.C., Quinn, N.W.T. and Benemann, A. (2010) A Realistic Technology and Engineering Assessment of Algae Biofuel Production. Energy Biosciences Institute, University of California, Berkeley. http://works.bepress.com/tlundqui/5/

[10] Sun, A., Davis, R., Starbuck, M., Ben-Amotz, A., Pate, R. and Piencos, P.T. (2011) Comparative Cost Analysis of Algal Oil Production for Biofuels. Energy, 36, 5169-5179. https://doi.org/10.1016/j.energy.2011.06.020

[11] Singh, R.N. and Sharma, S. (2012) Development of Suitable Photobioreactor for Algae Production-A Review. Renewable and Sustainable Energy Reviews, 16, 2347-2353. https://doi.org/10.1016/j.rser.2012.01.026

[12] Schenk, P.M., Thomas-Hall, S.R., Stephens, E., Marx, U.C., Mussgnug, J.H., Posten, C., Kruse, O. and Hankamer, B. (2008) Second Generation Biofuels: High-Efficiency Microalgae for Biodiesel Production. BioEnergy Research, 1, 20-43. https://doi.org/10.1007/s12155-008-9008-8

[13] Grobbelaar, J.U. (2000) Physiological and Technological Considerations for Optimizing Mass Algal Cultures. Journal of Applied Phycology, 12, 201-206. https://doi.org/10.1023/A:1008155125844

[14] Kunjapur, A.M. and Eldridge, R.B. (2010) Photobioreactor Design for Commercial Biofuel Production from Microalgae. Industrial and Engineering Chemistry Research, 49, 3516-3526. https://doi.org/10.1021/ie901459u

[15] Abomohra, A., Jin, W., Tu, R., Han, S., Eid, M. and Eladel, H. (2016) Microalgal Biomass Production as a Sustainable Feedstock for Biodiesel: Current Status and Perspectives. Renewable and Sustainable Energy Reviews, 64, 596-606. https://doi.org/10.1016/j.rser.2016.06.056

[16] Chisti, Y. (2008) Biodiesel from Microalgae Beats Bioethanol. Trends in Biotechnology, 26, 126-131. https://doi.org/10.1016/j.tibtech.2007.12.002

[17] Huang, Q., Jiang, F., Wang, L. and Yang, C. (2017) Design of Photobioreactors for Mass Cultivation of Photosynthetic Organisms. Engineering, 3, 318-329. https://doi.org/10.1016/J.ENG.2017.03.020

[18] Zhong, J.Y., Rong, J.F. and Zong, B.W. (2013) Factors in Mass Cultivation of Microalgae for Biodiesel. Chinese Journal of Catalysis, 34, 80-100. https://doi.org/10.1016/S1872-2067(11)60497-X

[19] Wang, B., Lan, C.Q. and Horsman, M. (2012) Closed Photobioreactors for Production of Microalgal Biomasses. Biotechnology Advances, 30, 904-912. https://doi.org/10.1016/j.biotechadv.2012.01.019

[20] Blanken, W., Cuaresma, M., Wijffels, R.H. and Janssen, M. (2013) Cultivation of Microalgae on Artificial Light Comes at a Cost. Algal Research, 2, 333-340. https://doi.org/10.1016/j.algal.2013.09.004

[21] Grima, E.M., Belarbi, E.-H., Fernández, F.A., Medina, A.R. and Chisti, Y. (2003) Recovery of Microalgal Biomass and Metabolites: Process Options and Economics, Biotechnology Advances, 20, 491-515. https://doi.org/10.1016/S0734-9750(02)00050-2

[22] Tredici, M.R. and Zittelli, G.C. (1998) Efficiency of Sunlight Utilization: Tubular versus Flat Photobioreactors. Biotechnology and Bioengineering, 57, 187-197. 
https://doi.org/10.1002/(SICI)1097-0290(19980120)57:2<187::AID-BIT7>3.0.CO;2-J

[23] Acien Fernandez, F.G., Fernandez Sevilla, J.M., Sanchez Perez, J.A., Molina Grima, E. and Chisti, Y. (2001) Airlift-Driven External-Loop Tubular Photobioreactors for Outdoor Production of Microalgae: Assessment of Design and Performance. Chemical Engineering Science, 56, 2721-2732.

https://doi.org/10.1016/S0009-2509(00)00521-2

[24] Tredici, M.R., Bassi, N., Prussi, M., Biondi, N., Rodolfi, L., Chini Zittelli, G. and Sampietro, G. (2015) Energy Balance of Algal Biomass Production in a 1-ha "Green Wall Panel” Plant: How to Produce Algal Biomass in a Closed Reactor Achieving a High Net Energy Ratio. Applied Energy, 154, 1103-1111.

https://doi.org/10.1016/j.apenergy.2015.01.086

[25] da Fontoura, J.T., Rolim, G.S., Farenzena, M. and Gutterres, M. (2017) Influence of Light Intensity and Tannery Wastewater Concentration on Biomass Production and Nutrient Removal by Microalgae Scenedesmus sp. Process Safety and Environmental Protection, 111, 355-362. https://doi.org/10.1016/j.psep.2017.07.024

[26] Richmond, A. (2004) Handbook of Microalgal Culture-Biotechnology and Applied Phycology. Blackwell Science, USA.

[27] Rai, M.P. and Gupta, S. (2017) Effect of Media Composition and Light Supply on Biomass, Lipid Content and Fame Profile for Quality Biofuel Production from Scenedesmus abundans. Energy Conversion and Management, 141, 85-92. https://doi.org/10.1016/j.enconman.2016.05.018

[28] Chisti, Y. (2007) Biodiesel from Microalgae. Biotechnology Advances, 25, 294-306. https://doi.org/10.1016/j.biotechadv.2007.02.001

[29] Vejrazka, C., et al. (2011) Photosynthetic Efficiency of Chlamydomonas reinhardtii in Flashing Light. Biotechnology and Bioengineering, 108, 2905-2913. https://doi.org/10.1002/bit.23270

[30] Vejrazka, C., et al. (2012) Photosynthetic Efficiency of Chlamydomonas reinhardtii in Attenuated, Flashing Light. Biotechnology and Bioengineering, 109, 2567-2574. https://doi.org/10.1002/bit.24525

[31] Acien Fernandez, F.G., Fernandez Sevilla, J.M. and Molina, G.E. (2013) Photobioreactors for the Production of Microalgae. Reviews in Environmental Science and Bio-Technology, 12, 131-151. https://doi.org/10.1007/s11157-012-9307-6

[32] Scott, S.A., Davey, M.P., Dennis, J.S., Horst, I., Howe, C.J., Lea-smith, D.J. and Smith, A.G. (2010) Biodiesel from Algae: Challenges and Prospects. Current Opinion in Biotechnol, 21, 277-286. https://doi.org/10.1016/j.copbio.2010.03.005

[33] Fernandez-Sevilla, J.M., Molina-Grima, E., Garcia-Camacho, F., Acien, F.G. and Sanchez-Perez, J.A. (1998) Photolimitation and Photoinhibition as Factors Determining Optimal Dilution Rate to Produce Eicosapentaenoic Acid from Cultures of the Microalga Isochrysis galbana. Applied Microbiology and Biotechnology, 50, 199-205. https://doi.org/10.1007/s002530051277

[34] Khanam, I. and Deb, U.K. (2016) Calculation of the Average Irradiance and the Microalgae Growth for a Year at CUET, Bangladesh. American Journal of Computational Mathematics, 6, 237-244. https://doi.org/10.4236/ajcm.2016.63024

[35] Molina-Grima, E., Garcia-Camacho, F., Sanchez-Perez, J.A., Fernandez-Sevilla, J.M., Acien, F.G. and Contreras-Gomez, A. (1994) A Mathematical Model of Microalgal Growth in Light-Limited Chemostat Culture. Journal of Chemical Technology \& Biotechnology, 61, 167-173. https://doi.org/10.1002/jctb.280610212

[36] Sanchez, J.F., Fernandez-Sevilla, J.M., Acien, F.G., Ceron, M.C., Perez-Parra, J. and 
Molina-Grima, E. (2008) Biomass and Lutein Productivity of Scenedesmus almeriensis. Influence of Irradiance, Dilution Rate and Temperature. Applied Microbiology and Biotechnology, 79, 719-729.

https://doi.org/10.1007/s00253-008-1494-2

[37] Gonçalves, A.L., Pires, J.C.M. and Simões, M. (2016) The Effects of Light and Temperature on Microalgal Growth and Nutrients Removal: An Experimental and Mathematical Approach. RCS Advances, 6, 22896-22907.

https://doi.org/10.1039/C5RA26117A

[38] Iasimone, F., Panico, A., de Felice, V., Fantasma, F., Iorizzi, M. and Pirozzi, F. (2018) Effect of Light Intensity and Nutrient Supply on Microalgae Cultivated in Urban Wastewater: Biomass Production, Lipids Accumulation and Settleability Characteristics. Journal of Environmental Management, 223, 1078-1085. https://doi.org/10.1016/j.jenvman.2018.07.024

[39] Schulze, P.S.C., Barreira, L.A., Pereira, H.G.C., Perales, J.A. and Varela, J.C.S. (2014) Light Emitting Diodes (LEDs) Applied to Microalgal Production. Trends in Biotechnology, 32, 422-430. https://doi.org/10.1016/j.tibtech.2014.06.001

[40] Schulze, P.S., Pereira, H.G., Santos, T.F., Schueler, L., Guerra, R., Barreira, L.A., Perales, J.A. and Varela, J.C. (2016) Effect of Light Quality Supplied by Light Emitting Diodes (LEDs) on Growth and Biochemical Profiles of Nannochloropsis oculata and Tetraselmis chuii. Algal Research, 16, 387-398.

https://doi.org/10.1016/j.algal.2016.03.034

[41] Lee, C.G. and Palsson, B. (1995) Light Emitting Diode-Based Algal Photobioreactor with External Gas Exchange. Journal of Fermentation and Bioengineering, 79, 257-263. https://doi.org/10.1016/0922-338X(95)90613-5

[42] Takache, H., Pruvost, J. and Marec, H. (2015) Investigation of Light/Dark Cycles Effects on the Photosynthetic Growth of Chlamydomonas Reinhardtii in Conditions Representative of Photobioreactor Cultivation. Algal Research, 8, 192-204. https://doi.org/10.1016/j.algal.2015.02.009

[43] Schulze, P.S.C. (2014) Effects of Light Quality Supplied by Light Emitting Diodes (LEDs) on Microalgal Production. Master's Thesis, Universidade do Algarve Faculdade de Ciências e Tecnologia, Algarve, Portugal.

[44] Satthong, S., Saego, K., Kitrungloadjanaporn, P., et al. (2019) Modeling the Effects of Light Sources on the Growth of Algae. Advances in Difference Equations, 2019, 170. https://doi.org/10.1186/s13662-019-2112-6

[45] Singh, S.P. and Singh, P. (2015) Effect of Temperature and Light on the Growth of Algae Species: A Review. Renewable \& Sustainable Energy Reviews, 50, 431-444. https://doi.org/10.1016/j.rser.2015.05.024

[46] Esteves, A.F., Soares, O.S.G.P., Vilar, V.J.P., Pires, J.C.M. and Gonçalves, A.L. (2020) The Effect of Light Wavelength on $\mathrm{CO}_{2}$ Capture, Biomass Production and Nutrient Uptake by Green Microalgae: A Step Forward on Process Integration and Optimisation. Energies, 13, 333. https://doi.org/10.3390/en13020333

[47] Fu, W., Guðmundsson, Ó., Paglia, G., Herjólfsson, G., Andrésson, Ó.S., Palsson, B.Ø. and Brynjólfsson, S. (2013) Enhancement of Carotenoid Biosynthesis in the Green Microalga Dunaliella salina with Light-Emitting Diodes and Adaptive Laboratory Evolution. Applied Microbiology and Biotechnology, 97, 2395-2403. https://doi.org/10.1007/s00253-012-4502-5

[48] Metsoviti, M.N., Papapolymerou, G., Karapanagiotidis, I.T. and Katsoulas, N. (2019) Effect of Light Intensity and Quality on Growth Rate and Composition of Chlorella vulgaris. Plants, 9, 31. https://doi.org/10.3390/plants9010031 
[49] Chia, S.R., Ong, H.C., Chew, K.W., Show, P.L., Phang, S.-M., Ling, T.C., et al. (2018) Sustainable Approaches for Algae Utilisation in Bioenergy Production. Renew Energy, 129, 838-852. https://doi.org/10.1016/j.renene.2017.04.001

[50] Chavan, K.J., Chouhan, S., Jain, S., Singh, P., Yadav, M. and Tiwari, A. (2014) Environmental Factors Influencing Algal Biodiesel Production. Environmental Engineering Science, 31, 602-611. https://doi.org/10.1089/ees.2014.0219

[51] Pancha, I., Chokshi, K. and Mishra, S. (2015) Enhanced Biofuel Production Potential with Nutritional Stress Amelioration through Optimization of Carbon Source and Light Intensity in Scenedesmus sp. CCNM 1077. Bioresource Technology, 179, 565-572. https://doi.org/10.1016/j.biortech.2014.12.079

[52] Seo, S.H., Ha, J.S., Yoo, C., Srivastava, A., Ahn, C.Y., Cho, D.H., et al. (2017) Light Intensity as Major Factor to Maximize Biomass and Lipid Productivity of Ettlia sp in $\mathrm{CO}_{2}$-Controlled Photoautotrophic Chemostat. Bioresource Technology, 244, 621-628. https://doi.org/10.1016/j.biortech.2017.08.020

[53] Cheirsilp, B. and Torpee, S. (2012) Enhanced Growth and Lipid Production of Microalgae under Mixotrophic Culture Condition: Effect of Light Intensity, Glucose Concentration and Fed-Batch Cultivation. Bioresource Technology, 110, 510-516. https://doi.org/10.1016/j.biortech.2012.01.125

[54] Choudhary, P., Bhattacharya, A., Prajapati, S.K., Kaushik, P. and Malik, A. (2015) Chapter 32-Phycoremediation-Coupled Biomethanation of Microalgal Biomass. In: Kim, S.-K., Ed., Handbook of Marine Microalgae, Academic Press, Boston, 483-499. https://doi.org/10.1016/B978-0-12-800776-1.00032-7

[55] Hu, Q., Sommerfeld, M., Jarvis, E., Ghirardi, M., Posewitz, M., Seibert, M., et al. (2008) Microalgal Triacylglycerols as Feedstocks for Biofuel Production: Perspectives and Advances. Plant Journal, 54, 621-639. https://doi.org/10.1111/j.1365-313X.2008.03492.x

[56] Zienkiewicz, K., Du, Z.Y., Ma, W., Vollheyde, K. and Benning, C. (2016) Stress-Induced Neutral Lipid Biosynthesis in Microalgae-Molecular, Cellular and Physiological Insights. Biochimica et Biophysica Acta, 1861, 1269-1281. https://doi.org/10.1016/j.bbalip.2016.02.008

[57] Gim, G.H., Ryu, J., Kim, M.J., Kim, P.I. and Kim, S.W. (2016) Effects of Carbon Source and Light Intensity on the Growth and Total Lipid Production of Three Microalgae under Different Culture Conditions. Journal of Industrial Microbiology \& Biotechnology, 43, 605-616. https://doi.org/10.1007/s10295-016-1741-y

[58] Kim, S., Moon, M., Kwak, M. and Lee, B. (2018) Statistical Optimization of Light Intensity and $\mathrm{CO}_{2}$ Concentration for Lipid Production Derived from Attached Cultivation of Green Microalga Ettlia sp. Scientific Reports, 8, 1-13.

https://doi.org/10.1038/s41598-018-33793-1

[59] Mandotra, S.K., Kumar, P., Suseela, M.R., Nayaka, S. and Ramteke, P.W. (2016) Evaluation of Fatty Acid Profile and Biodiesel Properties of Microalga Scenedesmus abundans under the Influence of Phosphorus, $\mathrm{pH}$ and Light Intensities. Bioresource Technology, 201, 222-229. https://doi.org/10.1016/j.biortech.2015.11.042

[60] Pribyl, P., Cepak, V. and Zachleder, V. (2012) Production of Lipids in 10 Strains of Chlorella and Parachlorella, and Enhanced Lipid Productivity in Chlorella vulgaris. Applied Microbiology and Biotechnology, 94, 549-561.

https://doi.org/10.1007/s00253-012-3915-5

[61] Mathimani, T., Uma, L. and Prabaharan, D. (2018) Formulation of Low-Cost Seawater Medium for High Cell Density and High Lipid Content of Chlorella vulgaris BDUG 91771 Using Central Composite Design in Biodiesel Perspective. Journal of 
Cleaner Production, 198, 575-586.

https://doi.org/10.1016/j.jclepro.2018.06.303

[62] Solovchenko, A.E. (2012) Physiological Role of Neutral Lipid Accumulation in Eukaryotic Microalgae under Stresses. Russian Journal of Plant Physiology, 59, 167-176. https://doi.org/10.1134/S1021443712020161

[63] George, B., Pancha, I., Desai, C., Chokshi, K., Paliwal, C., Ghosh, T., et al. (2014) Effects of Different Media Composition, Light Intensity and Photoperiod on Morphology and Physiology of freshwater Microalgae Ankistrodesmus falcatus-A Potential Strain for Bio-Fuel Production. Bioresource Technology, 171, 367-374. https://doi.org/10.1016/j.biortech.2014.08.086

[64] Nzayisenga, J.C., Farge, X., Groll, S.L., et al. (2020) Effects of Light Intensity on Growth and Lipid Production in Microalgae Grown in Wastewater. Biotechnology for Biofuels, 13, 4. https://doi.org/10.1186/s13068-019-1646-x

[65] Krzeminska, I., Piasecka, A., Nosalewicz, A., Simionato, D. and Wawrzykowski, J. (2015) Alterations of the Lipid Content and Fatty Acid Profile of Chlorella protothecoides under Different Light Intensities. Bioresource Technology, 196, 72-77. https://doi.org/10.1016/j.biortech.2015.07.043

[66] Cuhel, R.L., Ortner, P.B. and Lean, D.R.S. (1984) Night Synthesis of Protein by Algae. Limnology and Oceanography, 29, 731-744. https://doi.org/10.4319/lo.1984.29.4.0731

[67] He, Q., Yang, H., Wu, L. and Hu, C. (2015) Effect of Light Intensity on Physiological Changes, Carbon Allocation and Neutral Lipid Accumulation in Oleaginous Microalgae. Bioresource Technology, 191, 219-228. https://doi.org/10.1016/j.biortech.2015.05.021

[68] Brindley, C., Fernandez, F.A. and Fernandez-Sevilla, J. (2011) Analysis of Light Regime in Continuous Light Distributions in Photobioreactors. Bioresource Technology, 102, 3138-3148. https://doi.org/10.1016/j.biortech.2010.10.088

[69] Abu-Ghosh, S., Fixler, D., Dubinsky, Z., Solovchenko, A., Zigman, M., Yehoshua, Y. and Iluz, D. (2015) Flashing Light Enhancement of Photosynthesis and Growth Occurs When Photochemistry and Photoprotection Are Balanced in Dunaliella salina. European Journal of Phycology, 50, 469-480.

https://doi.org/10.1080/09670262.2015.1069404

[70] Schulze, P.S., Guerra, R., Pereira, H., Schuler, L.M. and Varela, J.C. (2017) Flashing LEDs for Microalgal Production. Trends in Biotechnology, 35, 1088-1101. https://doi.org/10.1016/j.tibtech.2017.07.011

[71] Schulze, P.C., Brindley, C., Fernandez, J.M., et al. (2019) Flashing Light Does Not Improve Photosynthetic Performance and Growth of Green Microalgae. Bioresource Technology Reports, 9, Article ID 100367. https://doi.org/10.1016/j.biteb.2019.100367

[72] Ota, M., Takenaka, M., Sato, Y., Lee, R., Jr, S. and Inomata, H. (2015) Effects of Light Intensity and Temperature on Photoautotrophic Growth of a Green Microalga, Chlorococcum littorale. Biotechnology Reports, 7, 24-29. https://doi.org/10.1016/j.btre.2015.05.001

[73] Qiang, H. and Richmond, A. (1996) Productivity and Photosynthetic Efficiency of Spirulina platensis as Affected by Light Intensity, Algal Density and Rate of Mixing in a Flat Plate Photobioreactor. Journal of Applied Phycology, 8, 139-145. https://doi.org/10.1007/BF02186317

[74] Xu, Y., Ibrahim, I.M. and Harvey, P.J. (2016) The Influence of Photoperiod and Light Intensity on the Growth and Photosynthesis of Dunaliella salina (chlorophy- 
ta) CCAP 19/30. Plant Physiology and Biochemistry, 106, 305-315. https://doi.org/10.1016/j.plaphy.2016.05.021

[75] Deb, U.K., Shahriar, M., Bhowmik, J. and Chowdury, M.K.H. (2017) The Effect of Irradiance Related Temperature on Microalgae Growth in a Tubular Photo Bioreactor for Cleaner Energy. American Journal of Computational Mathematics, 7, 371-384. https://doi.org/10.4236/ajcm.2017.73026

[76] Bernard, O. and Remond, B. (2012) Validation of a Simple Model Accounting for Light and Temperature Effect on Microalgal Growth. Bioresource Technology, 123, 520-527. https://doi.org/10.1016/j.biortech.2012.07.022

[77] Sánchez, J.F., Fernández, J.M., Acien, F.G., Rueda, A., Perez-Parra, J. and Molina, E. (2008) Influence of Culture Conditions on the Productivity and Lutein Content of the New Strain Scenedesmus almeriensis. Process Biochemistry, 43, 398-405. https://doi.org/10.1016/j.procbio.2008.01.004

[78] Bosma, R., Van Zessen, E., Reith, J.H., Tramper, J. and Wijffels, R.H. (2007) Prediction of Volumetric Productivity of an Outdoor Photobioreactor. Biotechnology and Bioengineering, 97, 1108-1120. https://doi.org/10.1002/bit.21319

[79] Huesemann, M.H., Van Wagenen, J., Miller, T., Chavis, A., Hobbs, S. and Crowe, B. (2013) A Screening Model to Predict Microalgae Biomass Growth in Photobioreactors and Raceway Ponds. Biotechnology and Bioengineering, 110, 1583-1594. https://doi.org/10.1002/bit.24814

[80] Torzillo, G. (1997) Tubular Bioreactors. In: Vonshak, A., Ed., Spirulina platensis (Arthrospira): Phisiology, cell-biology and biotechnology, Taylor and Francis, London, 101-115.

[81] Becker, E.W. (1994) Microalgae-Biotechnology and Microbiology. Cambridge University Press, Cambridge.

[82] Watanabe, Y., de la Noue, J. and Hall, D.O. (2011) Photosynthetic Performance of a Helical Tubular Photobioreactor Incorporating the Cyanobacterium Spirulina platensis. Biotechnology and Bioengineering, 47, 261-269. https://doi.org/10.1002/bit.260470218

[83] Thompson Jr., G.A. (1996) Lipids and Membrane Function in Green Algae. Biochimica et Biophysica Acta, 1302, 17-45. https://doi.org/10.1016/0005-2760(96)00045-8

[84] Harwood, J.L. (2004) Involvement of Chloroplast Lipids in the Reaction of Plants Submitted to Stress. In: Siegenthaler, P.A. and Murata, N., Eds., Lipids in Photosynthesis. Structure, Function and Genetics, Springer, Berlin, Germany, 6, 287-302. https://doi.org/10.1007/0-306-48087-5 15

[85] Guschina, I.A. and Harwood, J.L. (2009) Algal Lipids and Effect of the Environment on Their Biochemistry. In: Arts, M.T., Brett, M.T. and Kainz, M., Eds., Lipids in Aquatic Ecosystems, Springer, Berlin, Germany, 1-24. https://doi.org/10.1007/978-0-387-89366-2 1

[86] Binnal, P. and Babu, P.N. (2017) Statistical Optimization of Parameters Affecting Lipid Productivity of Microalga Chlorella Protothecoides Cultivated in Photobioreactor under Nitrogen Starvation. South African Journal of Chemical Engineering, 23, 26-37. https://doi.org/10.1016/j.sajce.2017.01.001

[87] Lee, S.J., Go, S., Jeong, G.T. and Kim, S.K. (2011) Oil Production from Five Marine Microalgae for the Production of Biodiesel. Biotechnology and Bioprocess Engineering, 16, 561-566. https://doi.org/10.1007/s12257-010-0360-0

[88] Wei, L., Huang, X. and Huang, Z. (2014) Temperature Effects on Lipid Properties of 
Microalgae Tetraselmis subcordiformis and Nannochloropsis oculata as Biofuel Resources. Chinese Journal of Oceanology and Limnology, 33, 99-106. https://doi.org/10.1007/s00343-015-3346-0

[89] Renaud, S.M., Thinh, L., Lambrinidis, G. and Parry, D.L. (2002) Effect of Temperature on Growth, Chemical Composition and Fatty Acid Composition of Tropical Australian Microalgae Grown in Batch Cultures. Aquaculture, 211, 195-214. https://doi.org/10.1016/S0044-8486(01)00875-4

[90] Gonçalves, A.L., Pires, J.C.M. and Simões, M. (2017) A Review on the Use of Microalgal Consortia for Wastewater Treatment. Algal Research, 24, 403-415. https://doi.org/10.1016/j.algal.2016.11.008

[91] Perez-Garcia, O., Escalante, F.M.E., de-Bashan, L.E. and Bashan, Y. (2011) Heterotrophic Cultures of Microalgae: Metabolism and Potential Products. Water Research, 45, 11-36. https://doi.org/10.1016/j.watres.2010.08.037

[92] Silva, N.F.P., Gonçalves, A.L., Moreira, F.C., Silva, T.F.C.V., Martins, F.G., Alvim-Ferraz, M.C.M., et al. (2015) Towards Sustainable Microalgal Biomass Production by Phycoremediation of a Synthetic Wastewater: A Kinetic Study. Algal Research, 11, 350-358. https://doi.org/10.1016/j.algal.2015.07.014

[93] Jia, H., Yuan, Q. and Rein, A. (2016) Removal of Nitrogen from Wastewater Using Microalgae and Microalgae-Bacteria Consortia. Cogent Environmental Science, 2, 1275089. https://doi.org/10.1080/23311843.2016.1275089

[94] Yang, J., Xu, M., Zhang, X., Hu, Q., Sommerfeld, M. and Chen, Y. (2011) Life-Cycle Analysis on Biodiesel Production from Microalgae: Water Footprint and Nutrients Balance. Bioresource Technology, 102, 159-165. https://doi.org/10.1016/j.biortech.2010.07.017

[95] Goiris, K., Van Colen, W., Wilches, I., León-Tamariz, F., De Cooman, L. and Muylaert, K. (2015) Impact of Nutrient Stress on Antioxidant Production in Three Species of Microalgae. Algal Research, 7, 51-57. https://doi.org/10.1016/j.algal.2014.12.002

[96] Sacristán de Alva, M., Luna Pabello, V.M., Orta Ledesma, M.T. and Cruz Gómez, M.J. (2018) Carbon, Nitrogen, and Phosphorus Removal, and Lipid Production by Three Saline Microalgae Grown in Synthetic Wastewater Irradiated with Different Photon Fluxes. Algal Research, 34, 97-103. https://doi.org/10.1016/j.algal.2018.07.006

[97] Markou, G., Vandamme, D. and Muylaert, K. (2014) Microalgal and Cyanobacterial Cultivation: The Supply of Nutrients. Water Research, 65, 186-202. https://doi.org/10.1016/j.watres.2014.07.025

[98] Borowitzka, M.A. (1988) Fats, Oils and Carbohydrates. In: Borowitzka, M.A. and Borowitzka, L.J., Eds., Micro-Algal Biotechnology, Cambridge University Press, Cambridge.

[99] Martin, J.H., Knauer, G.A., Karl, D.M. and Broenkow, W.W. (1987) VERTEX: Carbon Cycling in the Northeast Pacific. Deep Sea Research Part A. Oceanographic Research Papers, 34, 267-285. https://doi.org/10.1016/0198-0149(87)90086-0

[100] Minster, J.-F. and Boulahdid, M. (1987) Redfield Ratios along Isopycnal Surfaces-A Complementary Study. Deep Sea Research Part A. Oceanographic Research Papers, 34, 1981-2003. https://doi.org/10.1016/0198-0149(87)90094-X

[101] Shaffer, G., Bendtsen, J. and Ulloa, O. (1999) Fractionation during Remineralization of Organic Matter in the Ocean. Deep Sea Research Part I: Oceanographic Research Papers, 46, 185-204. https://doi.org/10.1016/S0967-0637(98)00061-2

[102] Takahashi, T., Broecker, W.S. and Langer, S. (1985) Redfield Ratio Based on Chem- 
ical Data from Isopycnal Surfaces. Journal of Geophysical Research: Oceans, 90, 6907-6924. https://doi.org/10.1029/JC090iC04p06907

[103] Matouke, M.M., Elewa, D.T. and Abdullahi, K. (2018) Binary Effect of Titanium Dioxide Nanoparticles (nTio 2 ) and Phosphorus on Microalgae (Chlorella Ellipsoides Gerneck, 1907). Aquatic Toxicology, 198, 40-48.

https://doi.org/10.1016/j.aquatox.2018.02.009

[104] Powell, N., Shilton, A., Chisti, Y. and Pratt, S. (2009) Towards a Luxury Uptake Process via Microalgae-Defining the Polyphosphate Dynamics. Water Research, 43, 4207-4213. https://doi.org/10.1016/j.watres.2009.06.011

[105] Richmond A. (2004) Handbook of Microalgal Culture-Biotechnology and Applied Phycologly. Chapter-5: Hu Q. Environmental Effects on Cell Composition. Blackwell Science, Oxford.

[106] Markou, G. and Georgakakis, D. (2011) Cultivation of Filamentous Cyanobacteria (Blue-Green Algae) in Agro-Industrial Wastes and Wastewaters: A Review. Applied Energy, 88, 3389-3401. https://doi.org/10.1016/j.apenergy.2010.12.042

[107] Hadiyanto, S., Rostika, R.N. and Handayani, N.A. (2012) Biofixation of Carbon Dioxide by Chlamydomonas sp. in a Tubular Photobioreactor. International Journal of Renewable Energy Development, 1, 10-14.

https://doi.org/10.14710/ijred.1.1.10-14

[108] Cho, S., Luong, T.T., Lee, D., Oh, Y.K. and Lee, T. (2011) Reuse of Effluent Water from a Municipal Wastewater Treatment Plant in Microalgae Cultivation for Biofuel Production. Bioresource Technology, 102, 8639-8645.

https://doi.org/10.1016/j.biortech.2011.03.037

[109] Park, J.B.K., Craggs, R.J. and Shilton, A.N. (2011) Wastewater Treatment High Rate Algal Ponds for Biofuel Production. Bioresource Technology, 102, 35-42. https://doi.org/10.1016/j.biortech.2010.06.158

[110] Durán, I., Rubiera, F. and Pevida, C. (2018) Microalgae: Potential Precursors of $\mathrm{CO}_{2}$ Adsorbents. Journal of $\mathrm{CO}_{2}$ Utilization, 26, 454-464. https://doi.org/10.1016/j.jcou.2018.06.001

[111] Ge, Y., Liu, J. and Tian, G. (2011) Growth Characteristics of Botryococcus braunii 765 under High $\mathrm{CO}_{2}$ Concentration in Photobioreactor. Bioresource Technology, 102, 130-134. https://doi.org/10.1016/j.biortech.2010.06.051

[112] Pires, J.C.M., Alvim-Ferraz, M.C.M., Martins, F.G. and Simões, M. (2012) Carbon Dioxide Capture from Flue Gases Using Microalgae: Engineering Aspects and Biorefinery Concept. Renewable and Sustainable Energy Reviews, 16, 3043-3053. https://doi.org/10.1016/j.rser.2012.02.055

[113] Anjos, M., Fernandes, B.D., Vicente, A.A., Teixeira, J.A. and Dragone, G. (2013) Optimization of $\mathrm{CO}_{2}$ Bio-Mitigation by Chlorella vulgaris. Bioresource Technology, 139, 149-154. https://doi.org/10.1016/j.biortech.2013.04.032

[114] Kasiri, S., Abdulsalam, S., Ulrich, A. and Prasad, V. (2015) Optimization of $\mathrm{CO}_{2}$ Fixation by Chlorella kessleri Using Response Surface Methodology. Chemical Engineering Science, 127, 31-39. https://doi.org/10.1016/j.ces.2015.01.008

[115] Qiu, R., Gao, S., Lopez, P.A. and Ogden, K.L. (2017) Effects of pH on Cell Growth, Lipid Production and $\mathrm{CO}_{2}$ Addition of Microalgae Chlorella sorokiniana. Algal Research, 28, 192-199. https://doi.org/10.1016/j.algal.2017.11.004

[116] Singh, N.K. and Dhar, D.W. (2011) Microalgae as Second Generation Biofuel: A Review. Agronomy for Sustainable Development, 31, 605-629.

https://doi.org/10.1007/s13593-011-0018-0 
[117] Zhu, L. (2015) Microalgal Culture Strategies for Biofuel Production: A Review. Biofuels, Bioproducts and Biorefining, 9, 801-814. https://doi.org/10.1002/bbb.1576

[118] Lu, D., Tabil, L.G., Wang, D., Wang, G. and Emami, S. (2014) Experimental Trials to Make Wheat Straw Pellets with Wood Residue and Binders. Biomass Bioenergy, 69, 287-296. https://doi.org/10.1016/j.biombioe.2014.07.029

[119] Wood, J.M. and Wang, H.-K. (1983) Microbial Resistance to Heavy Metals. Environmental Science \& Technology, 17, 582A-590A. https://doi.org/10.1021/es00118a717

[120] Lower, S.K. (1999) Carbonate Equilibria in Natural Waters. http://www.chem1.com/acad/pdf/c3carb.pdf

[121] Guštin, S. and Marinšek-Logar, R. (2011) Effect of pH, Temperature and Air Flow Rate on the Continuous Ammonia Stripping of the Anaerobic Digestion Effluent. Process Safety and Environmental Protection, 89, 61-66. https://doi.org/10.1016/j.psep.2010.11.001

[122] Cai, T., Park, S.Y. and Li, Y.B. (2013) Nutrient Recovery from Wastewater Streams by Microalgae: Status and Prospects. Renewable and Sustainable Energy Reviews, 19, 360-369. https://doi.org/10.1016/j.rser.2012.11.030

[123] Wang, L. and Nancollas, G.H. (2008) Calcium Orthophosphates: Crystallization and Dissolution. Chemical Reviews, 108, 4628-4669. https://doi.org/10.1021/cr0782574

[124] Chiranjeevi, P. and Mohan, S.V. (2016) Critical Parametric Influence on Microalgae Cultivation towards Maximizing Biomass Growth with Simultaneous Lipid Productivity. Renewable Energy, 98, 64-71. https://doi.org/10.1016/j.renene.2016.03.063

[125] Tripathi, R., Singh, J. and Thakur, I.S. (2015) Characterization of Microalga Scenedesmus sp. ISTGA1 for Potential $\mathrm{CO}_{2}$ Sequestration and Biodiesel Production. Renewable Energy, 74, 774-781. https://doi.org/10.1016/j.renene.2014.09.005

[126] Munir, N., Imtiaz, A., Sharif, N. and Naz, S. (2015) Optimization of Growth Conditions of Different Algal Strains and Determination of Their Lipid Contents. The Journal of Animal \& Plant Sciences, 25, 546-553.

[127] Wu, Y.H., Yu, Y., Hu, H.Y. and Zhuang, L.L. (2016) Effects of Cultivation Conditions on the Production of Soluble Algal Products (SAPs) of Scenedesmus sp. LX1. Algal Research, 16, 376-382. https://doi.org/10.1016/j.algal.2016.04.006

[128] Valdés, F.J., Hernández, M.R., Catalá, L. and Marcilla, A. (2012) Estimation of $\mathrm{CO}_{2}$ Stripping/ $\mathrm{CO}_{2}$ Microalgae Consumption Ratios in a Bubble Column Photobioreactor Using the Analysis of the $\mathrm{pH}$ Profiles. Application to Nannochloropsis oculata Microalgae Culture. Bioresource Technology, 119, 1-6. https://doi.org/10.1016/j.biortech.2012.05.120

[129] Moheimani, N.R. (2013) Inorganic Carbon and pH Effect on Growth and Lipid Productivity of Tetraselmis suecica and Chlorella sp (Chlorophyta) Grown Outdoors in Bag Photobioreactors. Journal of Applied Phycology, 25, 387-398. https://doi.org/10.1007/s10811-012-9873-6

[130] Venkata Mohan, S. and Devi, M.P. (2014) Salinity Stress Induced Lipid Synthesis to Harness Biodiesel during Dual Mode Cultivation of Mixotrophic Microalgae. Bioresource Technology, 165, 288-294. https://doi.org/10.1016/j.biortech.2014.02.103

[131] Brindley, C., Garcia-Malea, M.C., Acien, F.G., Fernandez, J.M., Garcia, J.L. and Molina, E. (2004) Influence of Power Supply in the Feasibility of Phaeodactylum Tricornutum Cultures. Biotechnology and Bioengineering, 87, 723-733. https://doi.org/10.1002/bit.20179 
[132] Suh, I.S. and Lee, C.G. (2003) Photobioreactor Engineering: Design and Performance. Biotechnology and Bioprocess Engineering, 8, 313-321. https://doi.org/10.1007/BF02949274

[133] Barbosa, M.J., Hadiyanto, H. and Wijffels, R.H. (2004) Overcoming Shear Stress of Microalgae Cultures in Sparged Photobioreactors. Biotechnology and Bioengineering, 85, 78-85. https://doi.org/10.1002/bit.10862

[134] Merchuk, J.C. and Wu, X. (2003) Modeling of Photobioreators: Application to Bubble Column Simulation. Journal of Applied Phycology, 15, 163-169. https://doi.org/10.1023/A:1023879619535

[135] Deb, U.K., Chayantrakom, K. and Lenbury, Y. (2012) Comparison of Single-Phase and Two-Phase Flow Dynamics in the HLTP for Microalgae Culture. International Journal of Mathematics and Computers in Simulation, 6, 496-503.

[136] Deb, U.K., Chayantrakom, K., Lenbury, Y. and Wiwatanapataphee, B. (2012) Numerical Simulation of Two-Phase Laminar Flow for $\mathrm{CO}_{2}$ and Microalgae Suspension in the HLTP. Proceedings of 11 th WSEAS International Conference on System Science and Computer Intelligence, Singapore, 11-13 May 2012, 53-58.

[137] Sánchez, A., Maceiras, R., Cancela, A. and Pérez, A. (2013) Culture Aspects of Isochrysis galbana for Biodiesel Production. Applied Energy, 101, 192-197. https://doi.org/10.1016/j.apenergy.2012.03.027

[138] Sobczuk, T.M., Camacho, F.G., Grima, E.M. and Chisti, Y. (2005) Effects of Agitation on the Microalgae Phaeodactylum tricornutum and Porphyridium cruentum. Bioprocess and Biosystems Engineering, 28, 243-250.

https://doi.org/10.1007/s00449-005-0030-3 